\title{
Classifying organic materials by oxygen-to-carbon elemental ratio to predict the activation regime of Cloud Condensation Nuclei (CCN)
}

\author{
M. Kuwata, W. Shao, R. Lebouteiller, and S. T. Martin \\ School of Engineering and Applied Sciences \& Department of Earth and Planetary Sciences, Harvard University, Cambridge, \\ Massachusetts, USA
}

Correspondence to: S. T. Martin (scot_martin@ harvard.edu)

Received: 28 November 2012 - Published in Atmos. Chem. Phys. Discuss.: 11 December 2012

Revised: 29 March 2013 - Accepted: 17 April 2013 - Published: 27 May 2013

\begin{abstract}
The governing highly soluble, slightly soluble, or insoluble activation regime of organic compounds as cloud condensation nuclei $(\mathrm{CCN})$ was examined as a function of oxygen-to-carbon elemental ratio $(\mathrm{O}: \mathrm{C})$. New data were collected for adipic, pimelic, suberic, azelaic, and pinonic acids. Secondary organic materials (SOMs) produced by $\alpha$-pinene ozonolysis and isoprene photo-oxidation were also included in the analysis. The saturation concentrations $C$ of the organic compounds in aqueous solutions served as the key parameter for delineating regimes of $\mathrm{CCN}$ activation, and the values of $C$ were tightly correlated to the $\mathrm{O}: \mathrm{C}$ ratios. The highly soluble, slightly soluble, and insoluble regimes of $\mathrm{CCN}$ activation were found to correspond to ranges of $[\mathrm{O}: \mathrm{C}]>0.6,0.2<[\mathrm{O}: \mathrm{C}]<0.6$, and $[\mathrm{O}: \mathrm{C}]<0.2$, respectively. These classifications were evaluated against $\mathrm{CCN}$ activation data of isoprene-derived SOM $(\mathrm{O}: \mathrm{C}=0.69-0.72)$ and $\alpha$-pinene-derived SOM $(\mathrm{O}: \mathrm{C}=0.38-0.48)$. Isoprene-derived SOM had highly soluble activation behavior, consistent with its high $\mathrm{O}: \mathrm{C}$ ratio. For $\alpha$-pinene-derived SOM, although $\mathrm{CCN}$ activation can be modeled as a highly soluble mechanism, this behavior was not predicted by the $\mathrm{O}: \mathrm{C}$ ratio, for which a slightly soluble mechanism was anticipated. Complexity in chemical composition, resulting in continuous water uptake and the absence of a deliquescence transition that can thermodynamically limit CCN activation, might explain the difference in the behavior of $\alpha$-pinene-derived SOM compared to that of pure organic compounds. The present results suggest that atmospheric particles dominated by hydrocarbon-like organic components do not activate (i.e., insoluble regime) whereas those dominated by oxygenated organic components activate (i.e., highly soluble regime) for typical atmospheric cloud life cycles.
\end{abstract}

\section{Introduction}

The cloud condensation nuclei $(\mathrm{CCN})$ activity of atmospheric particles affects particle lifetime and aging as well as their direct and indirect effects on climate (Twomey, 1977; Ramanathan et al., 2001; Stevens and Feingold, 2009). $\mathrm{CCN}$ activity of aerosol particles is dependent on size and chemical composition (McFiggans et al., 2006). Organic compounds are an important contributor to the $\mathrm{CCN}$ activity of atmospheric particles because of their abundance and hygroscopicity, although the complexity of their chemical composition challenges a systematic understanding of their effects (Novakov and Penner, 1993; Shulman et al., 1996; McFiggans et al., 2006; Jimenez et al., 2009). For instance, atmospheric organic particles have been estimated to be composed of more than a thousand compounds, yet only 10's to 100's of them are molecularly characterized (Hallquist et al., 2009; O'Brien et al., 2013). According to the Köhler theory, various properties of each organic compound in a particle affect $\mathrm{CCN}$ activity, including solubility, molecular weight, density, and non-ideality in aqueous solution (Shulman et al., 1996; Raymond and Pandis, 2002; McFiggans et al., 2006). Those complexities hinder accurate predictions of the contribution of organic compounds to the CCN activity of aerosol particles.

In the atmosphere, variability in size distribution is large, serving as a significant regulator of CCN number concentration (Dusek et al., 2006). Detailed chemical composition, especially the fraction of water-soluble materials, controls activation threshold diameter. Predicting the water solubility of atmospherically relevant compounds from measurable and predictable parameters is therefore important (Kuwata et al., 2008). 
The CCN activity of atmospherically relevant pure organic compounds has been investigated in many studies (Cruz and Pandis, 1997; Corrigan and Novakov, 1999; Prenni et al., 2001; Hartz et al., 2006; Hings et al., 2008). These studies demonstrate that the experimental results for highly water soluble compounds are well explained by the Köhler theory. By comparison, data for slightly soluble compounds are still difficult to interpret, in part because of significant variability in experimental data. For instance, the reported experimental results for the CCN activity of adipic acid particles vary widely, which is perhaps related to artifacts associated with particle generation methods (Hartz et al., 2006; Rissman et al., 2007; Hings et al., 2008). Data discrepancies have also been reported for pinonic acid (Raymond and Pandis, 2002; Hartz et al., 2006). These uncertainties should be reduced and ideally eliminated for accurate understanding of the effects of organic components on the $\mathrm{CCN}$ activity of atmospheric particles.

Secondary organic material (SOM), composed in large part of the low-volatility fraction of the oxidation products of volatile organic compounds, is one important subclass of atmospheric organic compounds and can be highly CCN active (Hartz et al., 2005; VanReken et al., 2005; King et al., 2007; Wex et al., 2009; Kuwata et al., 2011). Both laboratory and ambient SOM is composed of so many different compounds, uncharacterized both in identity and quantity, that the CCN activity of the composite particle cannot be predicted based on first-principle using molecular composition. An alternative approach for complex compositions is to base $\mathrm{CCN}$ activity on an aggregate quantity, such as the oxygen-to-carbon elemental ratio $(\mathrm{O}: \mathrm{C})$ of the organic material. The $\mathrm{O}: \mathrm{C}$ ratio is a parameter that can be both defined and measured for complex mixtures, as well as pure compounds, and initial studies have empirically demonstrated positive correlations between $\mathrm{O}: \mathrm{C}$ ratio and CCN activity in some cases (Chang et al., 2010; Kuwata et al., 2011; Lambe et al., 2011). A detailed understanding of the relationship, however, meaning one founded in theory and complemented by laboratory data, is still needed. This type of rational explanation can then be used to evaluate the capabilities, the limitations, and the possible extensions of the positive correlations reported between $\mathrm{O}: \mathrm{C}$ ratio and CCN activity.

In the present study, existing data are combined with new data for the CCN activities of pure organic compounds. A new particle generation system is developed for the study of slightly soluble compounds. The CCN activities of pure compounds, including both literature data and the new experimental results of this study, are analyzed with respect to their elemental ratios to establish a relationship between $\mathrm{CCN}$ activity and oxygen-to-carbon elemental ratio. The relationship between saturation water solubility and $\mathrm{O}: \mathrm{C}$ ratio is also investigated. These two relationships are combined to relate the regime of $\mathrm{CCN}$ activation to the $\mathrm{O}: \mathrm{C}$ elemental ratio. Finally, data for SOM CCN activity and $\mathrm{O}: \mathrm{C}$ ratio are used to test for differences between the behavior of pure compounds and that of a complex mixture of myriad compounds

\section{Theory}

\subsection{Köhler equation}

The hygroscopic growth and subsequent $\mathrm{CCN}$ activation of an aerosol particle can be described by the Köhler equation (Köhler, 1936; Seinfeld and Pandis, 2006):

$\ln s=\frac{4 \sigma M_{\mathrm{w}}}{R T \rho_{\mathrm{w}} d}+\ln a_{\mathrm{w}}$

Quantities include the saturation ratio $s$ of water vapor in the gas phase, the activity $a_{\mathrm{w}}$ of water in the particle phase, the surface tension $\sigma$ of water at the particle-gas interface, the molecular weight $M_{\mathrm{w}}$ of water, the universal gas constant $R$, the temperature $T$, the material density $\rho_{\mathrm{w}}$ of liquid water, and the diameter $d$ of the particle following water uptake. The first quantity of the RHS of Eq. (1) is referred to as the Kelvin term and the second quantity is known as the Raoult term. For CCN activation, supersaturation $S$ is defined as $S=s-1$. The critical supersaturation $S^{*}$ of a particle is the global maximum of $S(d)$ with respect to $d$. Particles activate as $\mathrm{CCN}$ for any environment or process that satisfies the thermodynamic condition $S>S^{*}$, although in addition to thermodynamics activation kinetics can sometimes also limit CCN activation (Ruehl et al., 2008).

For an aerosol particle constituted by $i$ different chemical components (plus water) and for water activity expressed by the molal osmotic coefficient $\varphi$ (Robinson and Stokes, 2002), Eq. (1) is re-written as follows (Raymond and Pandis, 2002; Seinfeld and Pandis, 2006; Petters and Kreidenweis, 2008):

$$
\begin{aligned}
& \ln s=\frac{4 \sigma M_{\mathrm{w}}}{R T \rho_{\mathrm{w}} d}-\frac{\varphi d_{0}^{3}}{d^{3}-d_{0}^{3}} \sum_{i} v_{i} f_{i} \varepsilon_{i} \frac{M_{\mathrm{w}} \rho_{i}}{M_{i} \rho_{\mathrm{w}}} \\
& \text { for } \varepsilon_{i}=\operatorname{Min}\left[1,\left(\frac{d^{3}}{d_{0}^{3}}-1\right) \frac{C_{i}}{f_{i}}\right]
\end{aligned}
$$

Quantities include the solute molecular weight $M_{i}$, the solute material density $\rho_{i}$ in pure form, the stoichiometric number $v_{i}$ of ions or molecules for ideal solute dissolution in water, the volume fraction $f_{i}$ of component $i$ in the particle in the absence of water, the dissolved solute fraction $\varepsilon_{i}$, the volume-based concentration ratio $C_{i}(v / v)$ of the pure compound in a saturated aqueous solution, and the diameter $d_{0}$ of the particle in the absence of water uptake. Independent behavior is assumed for the $i$ components in aqueous form, including the absence of mutual effects on solubility and non-ideality. The molal osmotic coefficient can be calculated using semi-emprical methods (Clegg and Seinfeld, 2006). The case of $\varepsilon_{i}=1$ corresponds to fully solubilized material and $0<\varepsilon_{i}<1$ indicates partially solubilized material. 
Depending on $C$, four different cases can be considered with respect to $S^{*}$ : (1) infinitely soluble, (2) highly soluble, (3) slightly soluble, and (4) insoluble (Fig. 1). Infinitely soluble particles are miscible with water, and in this case $\varepsilon_{i}$ is unity (Fig. 1, purple line). Highly soluble particles deliquesce at a lower supersaturation than $S^{*}$ (Fig. 1; red line), meaning $\varepsilon$ is again unity with respect to calculation of $S^{*}$. For the infinitely and highly soluble cases, the value of $S^{*}$ depends strongly on $M_{i}$ (Petters et al., 2009a). For the case of slightly soluble particles, deliquescence occurs at high $a_{\mathrm{w}}$, typically very close to unity (e.g., > 0.97) (Kreidenweis et al., 2006). Because of the Kelvin effect, the implication for particles of typical CCN sizes is that deliquescence occurs only in supersaturated environments (Fig. 1; blue line). For the case of insoluble particles, $a_{\mathrm{w}}$ equals unity, and the value of $S^{*}$ depends solely on the Kelvin effect (Fig. 1; black line). The behaviors described for these four cases correspond to the following domains of $C$ : (1) infinitely/highly soluble $\left(C>10^{-1}\right)$, (2) slightly soluble $\left(10^{-4}<C<10^{-1}\right)$, and (3) insoluble $\left(C<10^{-4}\right)$ (Petters and Kreidenweis, 2007; Sullivan et al., 2009).

In the case of $\varepsilon_{i}<1$ for all $i$, Eq. (2) simplifies as follows:

$\ln s=\frac{4 \sigma M_{\mathrm{w}}}{R T \rho_{\mathrm{w}} d}-\varphi \sum_{i}\left[v_{i} C_{i} \frac{M_{\mathrm{w}} \rho_{i}}{M_{i} \rho_{\mathrm{w}}}\right]$

The Raoult term depends on chemical composition but not on $d_{0}$ or $d$ because the aqueous phase is saturated (Raymond and Pandis, 2002). The associated physical description is that the particle consists of one phase of saturated aqueous solution and one phase of undissolved material. This equation is applicable to the case of $\mathrm{CCN}$ activation of slightly soluble particles: $S$ of initial deliquescence corresponds to $S^{*}$ because the diameter of the two-phase particle is continuously increasing and hence the Kelvin effect is continuously decreasing, even while $a_{\mathrm{w}}$ remains constant during the continuous dissolution process of initial to final deliquescence. For a deliquescence water activity $a_{\mathrm{w}, \mathrm{D}}$ of a slightly soluble particle, the value of $S^{*}$ is then given by the following equation.

$\ln \left(S^{*}+1\right)=\frac{4 \sigma M_{\mathrm{w}}}{R T \rho_{\mathrm{w}} d}+\ln a_{\mathrm{w}, \mathrm{D}}$

\subsection{Single parameter representing $\mathrm{CCN}$ activity}

The foregoing equations can be used to calculate $S^{*}$ so long as all the parameters are accurately known. The parameter values, however, are not always known, especially for atmospheric particles as well as for laboratory-generated SOM. An alternative representation of $\mathrm{CCN}$ activation is represented using a lumped-sum single parameter $\kappa$, which is approximately related to the fundamental quantities of Eqs. (1) to (4) as follows for highly soluble materials (Petters

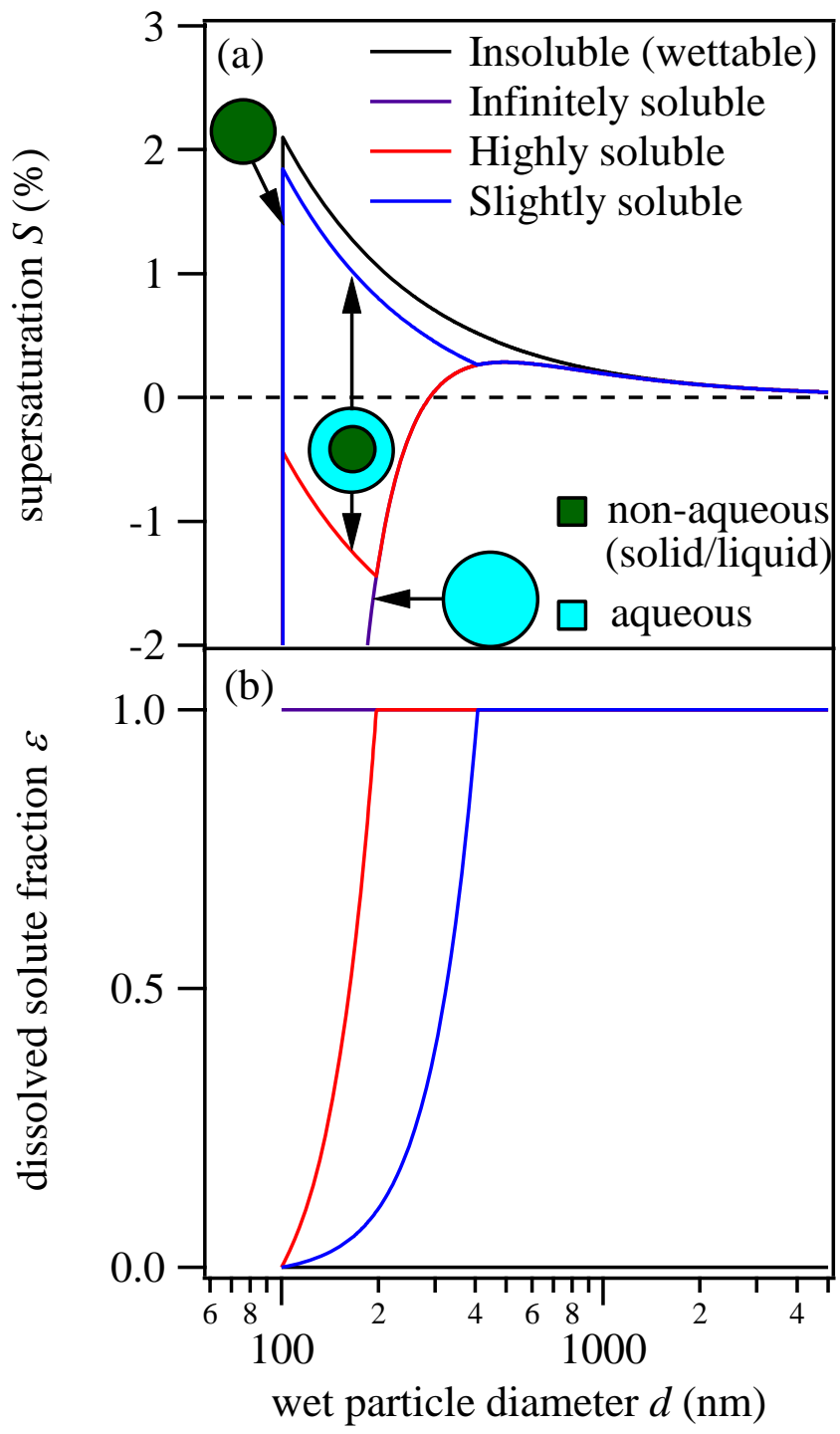

Fig. 1. Examples of Köhler curves for infinitely soluble (purple), highly soluble (red), slightly soluble (blue), and insoluble (black) particles. The calculations were conducted for input parameters of $\left\{M, \rho, \sigma, d_{0}\right\}=\left\{0.146 \mathrm{~kg} \mathrm{~mol}^{-1}, 1362 \mathrm{~kg} \mathrm{~m}^{-3}, 0.072 \mathrm{~J} \mathrm{~m}^{-2}\right.$, $100 \mathrm{~nm}\}$. The value of $C$ was taken as $0.15(v / v)$ for highly soluble particles and $0.015(v / v)$ for slightly soluble particles. Further explanation is provided in the text.

and Kreidenweis, 2007):

$\kappa=\left(v \varphi \frac{M_{\mathrm{w}}}{\rho_{\mathrm{w}}}\right)\left(\frac{\rho_{\mathrm{org}}}{M_{\mathrm{org}}}\right)$

This equation demonstrates that $\kappa$ is proportional to both $1 / M_{\text {org }}$ and $\rho_{\text {org. }}$. The value of $\kappa$ varies from 0 for insoluble materials (e.g., oleic acid) to 1.3 for highly soluble materials (e.g., sodium chloride). 
Table 1. Properties of tested organic compounds.

\begin{tabular}{llcccccc}
\hline Compound & Formula & $M_{\text {org }}\left(\mathrm{kg} \mathrm{mol}^{-1}\right)$ & $\mathrm{O}: \mathrm{C}$ & $\mathrm{H}: \mathrm{C}$ & $\rho^{\mathrm{a}}\left(\mathrm{kg} \mathrm{m}^{-3}\right)$ & $C^{\mathrm{b}}(v / v)$ & $\sigma^{\mathrm{a}, \mathrm{c}}\left(\mathrm{J} \mathrm{m}^{-2}\right)$ \\
\hline adipic acid & $\mathrm{C}_{6} \mathrm{H}_{10} \mathrm{O}_{4}$ & 0.146 & 0.67 & 1.67 & 1362 & $1.8 \times 10^{-2}$ & 0.066 \\
pimelic acid & $\mathrm{C}_{7} \mathrm{H}_{12} \mathrm{O}_{4}$ & 0.160 & 0.57 & 1.71 & 1321 & $4.9 \times 10^{-2}$ & 0.049 \\
suberic acid & $\mathrm{C}_{8} \mathrm{H}_{14} \mathrm{O}_{4}$ & 0.174 & 0.50 & 1.75 & 1272 & $1.8 \times 10^{-3}$ & 0.055 \\
azelaic acid & $\mathrm{C}_{9} \mathrm{H}_{16} \mathrm{O}_{4}$ & 0.188 & 0.44 & 1.78 & 1251 & $1.4 \times 10^{-3}$ & 0.059 \\
pinonic acid & $\mathrm{C}_{10} \mathrm{H}_{16} \mathrm{O}_{3}$ & 0.184 & 0.30 & 1.60 & 1169 & $5.5 \times 10^{-3 \mathrm{a}}$ & 0.053 \\
\hline
\end{tabular}

\footnotetext{
a Hartz et al. (2006).

${ }^{\mathrm{b}} \mathrm{C}$ is from the empirical fit of experimental data $\left(25^{\circ} \mathrm{C}\right.$, Appendix A1), except for pinonic acid.

${ }^{c}$ Values are for saturated aqueous solutions.
}

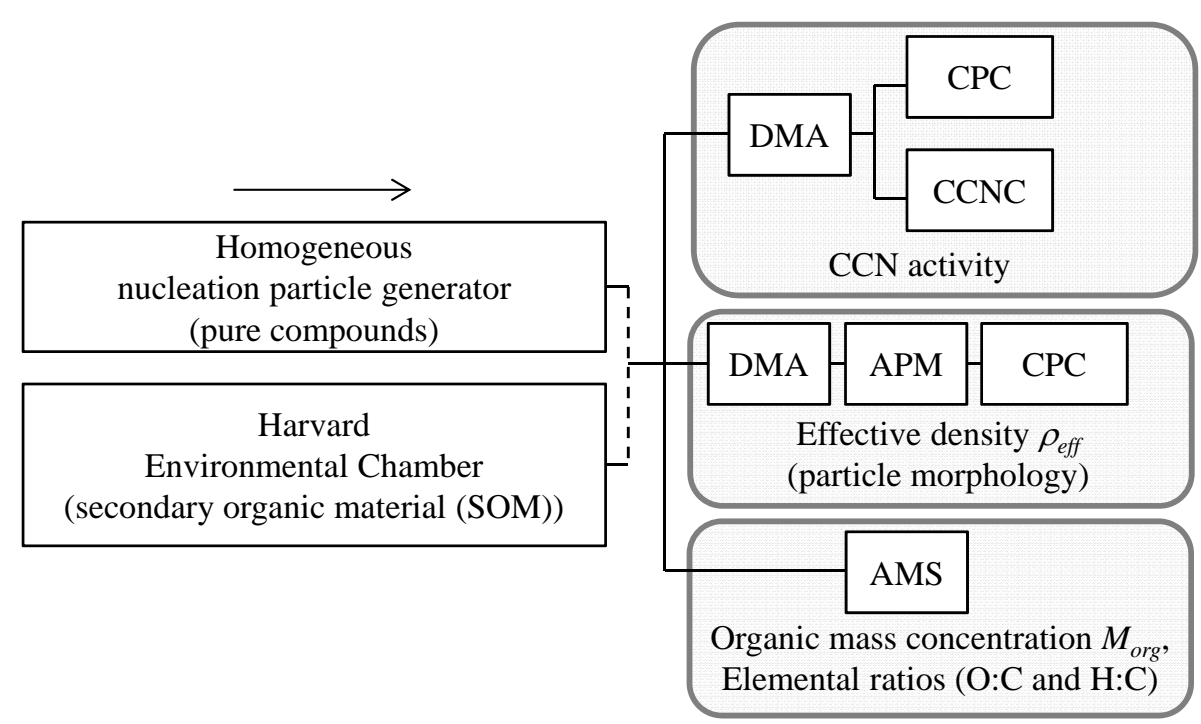

Fig. 2. Experimental setup. Abbreviations: TSI Differential Mobility Analyzer (DMA); TSI Condensation Particle Counter (CPC); DMT Cloud Condensation Nuclei Counter (CCNC); KANOMAX Aerosol Particle Mass Analyzer (APM); and Aerodyne Aerosol Mass Spectrometer (AMS).

For a particle of dry diameter $d_{0}$ and parameter $\kappa$, the critical supersaturation is given as follows:

$\kappa d_{0}^{3} \ln ^{2} S^{*}=\frac{4}{27}\left(\frac{4 \sigma M_{\mathrm{w}}}{R T \rho_{\mathrm{w}}}\right)^{3}$

Although $\sigma$ is in principle a function of both chemical composition and solute concentration, such information is rarely available, and the value of water is taken by definition for $\kappa$. Other quantities on the RHS of Eq. (6) are taken for $300 \mathrm{~K}$ for the definition of $\kappa$. The value of $\kappa$ directly relates $d_{0}$ and $S^{*}$, and this relationship is obtained either by theoretical or experimental approaches. The utility of $\kappa$ is that it is approximately constant for variable $d_{0}$, at least for some ideal cases.

\section{Experimental}

The experimental setup is represented in Fig. 2. In overview, particles produced either in a custom evaporation- condensation generator or in the Harvard Environmental Chamber (HEC) were characterized for their CCN activity and effective density $\rho_{\text {eff }}$ (Shilling et al., 2008; Chen et al., 2011; Kuwata and Martin, 2012b). Particle organic mass concentrations $M_{\text {org }}$ as well as elemental ratios were also measured using a high-resolution Aerodyne Aerosol Mass Spectrometer (AMS) (DeCarlo et al., 2006).

In a first set of experiments, particles of five pure organic compounds were tested, including adipic, pimelic, suberic, azelaic, and pinonic acid (Table 1) (Sigma-Aldrich, purity $>98 \%$ ). The chemicals were received as powders, and aerosol particles were produced by evaporation of the powders at elevated temperature ( $>373 \mathrm{~K}$, depending on compounds), homogeneous nucleation of new particles from the hot vapors, and condensation and coagulation growth of those particles (cf. Supplement). The particle generator consisted of a heated U-tube (inner diameter of $10 \mathrm{~mm}$ ) and an air-cooled condenser (Kuwata and Martin, 2012b). The chemicals were placed at the bottom of the U-tube, which was encased by a ribbon heater (Omega Engineering Inc. 
Table 2. Summary of experimental conditions for the HEC experiments.

\begin{tabular}{|c|c|c|c|c|c|c|c|c|}
\hline & Reaction conditions & & Seed particles & & Measured quantities & & & \\
\hline Exp & Precursor compound & relative humidity (\%) & diameter (nm) & phase & $\begin{array}{l}\text { organic particle mass } \\
\text { concentration }\left(\mu \mathrm{g} \mathrm{m}^{-3}\right)^{*}\end{array}$ & $\mathrm{H}: \mathrm{C}$ & $\mathrm{O}: \mathrm{C}$ & $\kappa$ \\
\hline 1 & $\alpha$-pinene & 40 & 30 & dry & 1.4 & 1.40 & 0.48 & 0.10 \\
\hline 2 & $\alpha$-pinene & 40 & 30 & dry & 5.7 & 1.43 & 0.44 & 0.10 \\
\hline 3 & $\alpha$-pinene & 40 & 30 & dry & 10 & 1.43 & 0.41 & 0.11 \\
\hline 4 & $\alpha$-pinene & 40 & 30 & dry & 25 & 1.46 & 0.40 & 0.10 \\
\hline 5 & $\alpha$-pinene & 40 & 30 & dry & 37 & 1.47 & 0.38 & 0.11 \\
\hline 6 & isoprene & 40 & 30 & dry & 37 & 1.86 & 0.71 & 0.17 \\
\hline 7 & isoprene & 40 & 30 & wet & 19 & 1.84 & 0.72 & 0.16 \\
\hline 8 & isoprene & 60 & 30 & dry & 15 & 1.79 & 0.72 & 0.15 \\
\hline 9 & isoprene & 60 & 30 & wet & 18 & 1.84 & 0.69 & 0.16 \\
\hline
\end{tabular}

* Not corrected for bag wall loss (Shilling et al., 2008).

FGS0031) to induce vaporization. Pure air (AADCO model 737) continuously flowed through the U-tube. A flow rate of 1 to $10 \mathrm{Lpm}$ was used depending on experimental conditions. Higher (lower) flow rates favored the production of smaller (larger) particles. Vapors of the organic compounds were transferred from the evaporator to the condenser in the pure air flow. New particle formation occurred in the condenser by homogeneous nucleation, and the fresh nuclei grew downstream by coagulation and condensation mechanisms. Particles exiting the condenser were mixed with pure air to regulate number concentration to no more than $3000 \mathrm{~cm}^{-3}$ (Lathem and Nenes, 2011). This particle generation method had the advantage of producing crystalline, solid particles of high purity (Hings et al., 2008; Biskos et al., 2009; Kuwata and Martin, 2012b). For instance, AMS analysis of adipic acid particles produced by atomization of an aqueous solution showed the presence of significant ammonia even with extensive efforts to purify the water. By comparison, AMS analysis of the evaporation-condensation particles had an absence of any significant ammonia peak (Kuwata and Martin, 2012b).

A second set of experiments focused on particles of secondary organic material extracted from the outflow of the Harvard Environmental Chamber. Methods were similar as described previously (Kuwata et al., 2011, 2012). Briefly, SOM produced by $\alpha$-pinene dark ozonolysis or isoprene phtooxidation condensed onto the surface of ammonium sulfate seed particles, which then continued to grow by additional SOM condensation (Kuwata and Martin, 2012a). Prior to entering the continuous-flow chamber, the seed particles were size-classified by a differential mobility analyzer (DMA) to an electric mobility diameter of $30 \mathrm{~nm}$ (+1 charge). The particles exiting the chamber varied in diameter from 30 to $300 \mathrm{~nm}$ depending on an individual particle residence time ( 0 to $12 \mathrm{~h}$ ). Table 2 presents a summary of the different conditions used for the conducted experiments.
Particles from both sets of experiments were characterized for the single parameter $\kappa$ that quantified $\mathrm{CCN}$ activity and for particle effective density $\rho_{\text {eff. }}$. Measurement methods and calibration procedures followed those described in Kuwata and Kondo (2009) and Kuwata et al. (2011). In brief, after passage through a diffusion dryer (only for SOM particles) and variable size selection by a DMA (TSI model 3071), the number fraction of CCN active particles was quantified by taking the ratio of the number concentration of a CCN counter (CCNC) (Roberts and Nenes, 2005) set to a specific supersaturation $S(0.2$ to $1.0 \%)$ to the total number concentration of a condensation particle counter (CPC, TSI model 3022). The CCNC was calibrated using ammonium sulfate particles. The maximum temperature inside of the CCNC during the course of experiments was $311 \mathrm{~K}$ at the bottom of the column, corresponding to the highest $S(1 \%)$. The $\mathrm{CCN}$ activation curves (i.e., the number fraction of $\mathrm{CCN}$ active particles plotted against particle diameter) were fit by sigmoid functions, and the midpoint diameter was taken as $d_{0}$ and used to determine the value of $\kappa$ (Kuwata et al., 2011). The volume fraction of the SOM was greater than 0.95 for the analyzed particles (i.e., $>80 \mathrm{~nm}$ ), and a correction was included in the analysis based on volume additivity between sulfate $(<5 \%)$ and SOM (Kuwata et al., 2011). Particle effective density $\rho_{\text {eff }}$ was measured using a DMA in serial connection to an aerosol particle mass analyzer (APM) (Ehara et al., 1996; McMurry et al., 2002). The value of $\rho_{\text {eff }}$ is smaller than material density for particles of non-spherical shape (Kuwata and Kondo, 2009). The value of $\rho_{\text {eff }}$ was used to obtain accurate values of volume-equivalent diameter $d_{\mathrm{ve}}$ (i.e., $d_{0}$ ) for interpretation of the $\mathrm{CCN}$ data in the experiments that used pure compounds. 
Table 3. Values of single parameter $\kappa$ for organic compounds tested in this study. Raw data are presented in the Supplement.

\begin{tabular}{|c|c|c|}
\hline Compound & & $\kappa^{\mathrm{a}}$ \\
\hline \multirow[t]{2}{*}{ Adipic acid } & experiment & $\begin{array}{l}0.002-0.003 \text { (this study) } \\
0.097 \text { (Cruz and Pandis, 1997) } \\
0.030 \text { (Corrigan and Novakov, 1999) } \\
0.013 \text { (Prenni et al., 2001) } \\
0.01-0.03 \text { (Raymond and Pandis, 2002) } \\
0.004-0.01 \text { (Broekhuizen et al., 2004) } \\
0.003 \text { (Hartz et al., 2006) } \\
0.05-0.08 \text { (Rissman et al., 2007) } \\
0.003-0.22 \text { (Hings et al., 2008) }\end{array}$ \\
\hline & theory & $\begin{array}{l}0.16\left(\text { case } 1^{b}\right) \\
0.001-0.004\left(\text { case } 2^{c}\right)\end{array}$ \\
\hline \multirow[t]{2}{*}{ Pimelic acid } & experiment & $\begin{array}{l}0.14-0.16 \text { (this study) } \\
0.14 \text { (Hartz et al., 2006) } \\
0.15 \text { (Frosch et al., 2010) }\end{array}$ \\
\hline & theory & $\begin{array}{l}0.15\left(\text { case } 1^{b}\right) \\
0.03\left(\text { case } 2^{c}\right)\end{array}$ \\
\hline \multirow[t]{2}{*}{ Suberic acid } & experiment & $\begin{array}{l}0.001 \text { (this study) } \\
0.001 \text { (Hartz et al., 2006) }\end{array}$ \\
\hline & theory & $\begin{array}{l}0.13\left(\text { case } 1^{b}\right) \\
0.002-0.003\left(\text { case } 2^{c}\right)\end{array}$ \\
\hline \multirow[t]{2}{*}{ Azelaic acid } & experiment & $\begin{array}{l}0.02-0.04 \text { (this study) } \\
0.02 \text { (Hartz et al., 2006) }\end{array}$ \\
\hline & theory & $\begin{array}{l}0.12\left(\text { case } 1^{b}\right) \\
0.001-0.002\left(\text { case } 2^{c}\right)\end{array}$ \\
\hline \multirow[t]{2}{*}{ Pinonic acid } & experiment & $\begin{array}{l}0.01 \text { (this study) } \\
0.1 \text { (Raymond and Pandis, 2002) } \\
0.009-0.04 \text { (Hartz et al., 2006) }\end{array}$ \\
\hline & theory & $\begin{array}{l}0.11\left(\text { case } 1^{b}\right) \\
0.001-0.003\left(\text { case } 2^{c}\right)\end{array}$ \\
\hline $\begin{array}{l}\text { Equation (6) v } \\
\text { f water }(0.072 \\
\text { Equation }(2) \\
\text { raction } \varepsilon \text { is alw } \\
\text { vater. } \\
\text { Equation (2) } \\
\text { nd the surface }\end{array}$ & $\begin{array}{l}\text { used to calcu } \\
-2) \text {. } \\
\text { employed to } \\
\text { unity, and th } \\
\text { employed to } \\
\text { sion } \sigma \text { of satu }\end{array}$ & $\begin{array}{l}\text { te the values assuming a value for } \sigma \text { of that } \\
\text { lculate } S^{*} \text {, assuming that dissolved solute } \\
\text { value of surface tension } \sigma \text { is equal to that of } \\
\text { lculate } S^{*} \text {, using the solubility data at } 25^{\circ} \mathrm{C} \text {, } \\
\text { ted aqueous solution (Table } 1 \text { ). }\end{array}$ \\
\hline
\end{tabular}

\section{Results}

\subsection{Pure compounds}

The CCN activation curves are presented in the Supplement (Shao, 2012). The $\kappa$ and $a_{\mathrm{w}, \mathrm{D}}$ values were obtained by analysis of the data using Eqs. (4) and (6). Adipic, suberic, azelaic, and pinonic acids activated as slightly soluble particles. By comparison, pimelic acid activated as a highly soluble particle. The experimentally determined $\kappa$ values along with theoretical predictions and literature data are listed in Table 3.

\subsubsection{Adipic acid}

The CCN activity of adipic acid particles has been intensely investigated, yet the experimental data of different studies are inconsistent, with $\kappa$ ranging from 0.003 to 0.22 (Cruz and Pandis, 1997; Corrigan and Novakov, 1999; Prenni et al., 2001; Raymond and Pandis, 2002; Broekhuizen et al., 2004; Hartz et al., 2006; Rissman et al., 2007; Hings et al., 2008). Particle phase as well as impurities are possibly responsible for the variability among studies (Rissman et al., 2007; Hings et al., 2008). Our present experimental result for $\kappa=0.002$ to 0.003 agrees with the theoretical prediction, corresponding to the lower edge of literature data (Table 3). The value of $a_{\mathrm{w}, \mathrm{D}}$ estimated from the experimental data agrees with that reported by Chan et al. (2008) as well as that predicted from the value of $C$, at least within the uncertainty of the measurements (Table 4) (Gaivoronskii and Granzhan, 2005). This agreement indicates the merit in using vaporization-condensation method in generating organic aerosol particles, which minimizes contaminations and ambiguity in phase by avoiding interaction with water molecules (Kuwata and Martin, 2012b).

\subsubsection{Pimelic acid}

The value of $\kappa=0.14$ to 0.16 observed for pimelic acid particles is similar to values reported by previous studies (Hartz et al., 2006; Frosch et al., 2010). The combined results indicate that pimelic acid particles are highly soluble. By comparison, theoretical calculations anticipate slightly soluble particles because $C=0.04$ at $293 \mathrm{~K}$ (Hartz et al., 2006).

Some technical issues associated with CCNC instrumentation, as well as particle production methods, must be considered in elucidating possible reasons for the discrepancy among the theoretical prediction and experimental observations. There are temperature gradients inside the instruments that can significantly influence $\mathrm{CCN}$ activation for compounds that have high sensitivity with respect to temperature-dependent solubility (Asa-Awuku et al., 2009; Christensen and Petters, 2012). Apelblat and Manzurola (1989) reported a significant temperature dependence for the solubility of pimelic acid, more so than for the other studied acids (Appendix A1). The highest temperature in the CCNC during the measurement of pimelic acid particles was $303 \mathrm{~K}$, corresponding to the lower section of the instrument. At this temperature, the value of $C=0.06$ borders between highly and slightly soluble, leading to a hypothesis that the elevated temperature in the instrument altered the $\mathrm{CCN}$ activation regime of the pimelic acid particles. $\mathrm{CCN}$ activity of pimelic acid particles is in particular sensitive to temperature because the solubility at room temperature is on the border between slightly and highly soluble cases. Temperature dependences in solubility have also been investigated for other organic compounds, yet such regime shifts were not observed for these cases (Appendix A1). A systematic experiment on the temperature dependence is motivated for confirming this explanation for pimelic acid (Christensen and Petters, 2012). Another possibility is that impurities such as ammonia could affect solubility, as in the case of adipic 
Table 4. Values of water activity $a_{\mathrm{w}, \mathrm{D}}$ of deliquescence based on CCN activation data. Data from Chan et al. (2008) are listed for comparison.

\begin{tabular}{llll}
\hline Compound & $a_{\mathrm{w}, \mathrm{D}}$ (this study) $^{\mathrm{a}}$ & $\left.a_{\mathrm{w}, \mathrm{D}}{\text { (ideal solution })^{\mathrm{c}}}^{a_{\mathrm{w}, \mathrm{D}}(\text { Chan et al., 2008) }}\right)^{\mathrm{d}}$ \\
\hline Adipic acid & $0.998-0.999$ & $0.994-0.998\left(20-40^{\circ} \mathrm{C}\right)$ & 0.998 \\
Pimelic acid & $<0.988^{\mathrm{b}}$ & $0.986-0.994\left(20-37^{\circ} \mathrm{C}\right)$ & 0.995 \\
Suberic acid & $\sim 1$ & $0.999\left(20-40^{\circ} \mathrm{C}\right)$ & 0.999 \\
Azelaic acid & $0.988-0.996$ & $0.999\left(20-40^{\circ} \mathrm{C}\right)$ & 0.999 \\
Pinonic acid & $0.995-0.997$ & 0.999 & \\
\hline
\end{tabular}

${ }^{a}$ Calculated using equation 4 for the surface tension of a saturated solution (Table 1).

$\mathrm{b}$ The value corresponds to the maximum estimate for highly soluble activation mechanism.

${ }^{\mathrm{c}}$ Calculated using Eq. (A2).

${ }^{\mathrm{d}}$ Chan et al. (2008) measured $a_{\mathrm{w}, \mathrm{D}}$ at $23^{\circ} \mathrm{C}$ for a stated uncertainty of \pm 0.003 by the experimental approach of

measuring the water activity of saturated aqueous solutions.

acid (Hings et al., 2008; Kuwata and Martin, 2012b). Other factors, such as particle morphology, changes in surface tension at elevated temperature, or non-ideality of solution, might also influence the activation.

\subsubsection{Suberic acid}

The experimental result of $\kappa=0.001$ for suberic acid is well explained as slightly soluble, consistent with the literature data (Table 3) (Hartz et al., 2006). The derived value of $a_{\mathrm{w}, \mathrm{D}}$ is approximately unity, consistent with the measurements made for bulk solutions (Table 4).

\subsubsection{Azelaic acid}

The measured value for $\kappa$ was 0.02 to 0.03 for azelaic acid, in agreement with the literature (Hartz et al., 2006). This value characterizes a slightly soluble material. It is higher than the theoretically predicted value of $0.001-0.002$ based on solubility data. Correspondingly, $a_{\mathrm{w}, \mathrm{D}}=0.988$ to 0.996 , as estimated from the experimental result, is smaller than $a_{\mathrm{w}, \mathrm{D}}=0.999$ as reported in the literature and as predicted from solubility data (Chan et al., 2008). Uncertainties in the experiment, as well as uncertainties in the input parameters for the theoretical calculation, must be considered to fully understand the $\mathrm{CCN}$ activity of the azelaic acid particles (i.e., as listed above for pimelic acid).

\subsubsection{Pinonic acid}

The experimental results show that pinonic acid activates in the slightly soluble regime (Table 3 ). This result agrees with that of Hartz et al. (2006) but contradicts the report of Raymond and Pandis (2002). Particle phase appears to affect the CCN activity of this compound, as is the case for other compounds such as adipic acid (Hartz et al., 2006). The experimentally determined $\kappa$ value of 0.01 is higher than the theoretical prediction of $\kappa=0.001$ to 0.003 . Correspondingly, as for azelaic acid, $a_{\mathrm{w}, \mathrm{D}}=0.995$ is smaller than $a_{\mathrm{w}, \mathrm{D}}=0.999$ as reported in the literature (Table 3 and 4).

\subsection{SOM particles}

The $\kappa, \mathrm{O}: \mathrm{C}$, and $\mathrm{H}: \mathrm{C}$ values obtained by measurement of $\alpha$-pinene-derived and isoprene-derived SOM particles are listed in Table 2. The results for the $\alpha$-pinene SOM particles are discussed in detail by Kuwata et al. (2011), for which $\kappa=0.1$ is obtained in agreement with literature (King et al., 2009; Wex et al., 2009; Frosch et al., 2011). For isoprene-derived SOM particles, $\kappa$ of $0.15-0.17$ was obtained, irrespective of the seed particle phase and the $\mathrm{RH}$ in the chamber. The obtained $\kappa$ value is in agreement with literature reports $(\kappa=0.12 \pm 0.06)$ (King et al., 2010; Engelhart et al., 2011; Lambe et al., 2011). The variability in the literature reports might be related to different chemical aging processes (Engelhart et al., 2011; Lambe et al., 2011). Elemental ratios of isoprene SOM are consistent with those reported by Chen et al. (2011). The results were not sensitive to seed particle phase as well as RH, at least for our experimental data set.

\section{Discussion}

\subsection{Relationship of $C$ to $\mathrm{O}: \mathrm{C}$}

Plots of $C$ and $\kappa$ versus $\mathrm{O}: \mathrm{C}$ are shown in Fig. 3 for the investigated compounds, including lines that demarcate highly soluble, slightly soluble, and insoluble regimes (Table 5; Appendix A2). The sources of the original data set include this study as well as literature (Corrigan and Novakov, 1999; Raymond and Pandis, 2002; Hori et al., 2003; Pradeep Kumar et al., 2003; Hartz et al., 2006; Rosenorn et al., 2006; Shilling et al., 2007; Petters et al., 2009a). In Fig. 3a of $C$ versus $O: C$, there is a trend of increasing $C$ for greater $\mathrm{O}: \mathrm{C}$. For compounds of $\mathrm{O}: \mathrm{C}<0.2$, all of the investigated compounds are insoluble based on $C$. For $0.2<\mathrm{O}: \mathrm{C}<0.6$, most compounds are slightly soluble, although water soluble polymers are an exception. Those polymers have large $\mathrm{H}: \mathrm{C}$, suggesting the use of $\mathrm{H}: \mathrm{C}$ in conjunction with $\mathrm{O}: \mathrm{C}$ for more accurate estimates of $C$ 
dicarboxylic acids
benzoic acids
carbohydrates
fatty acids
soluble polymers
$\triangle$ other
$\triangle$ isoprene SOM

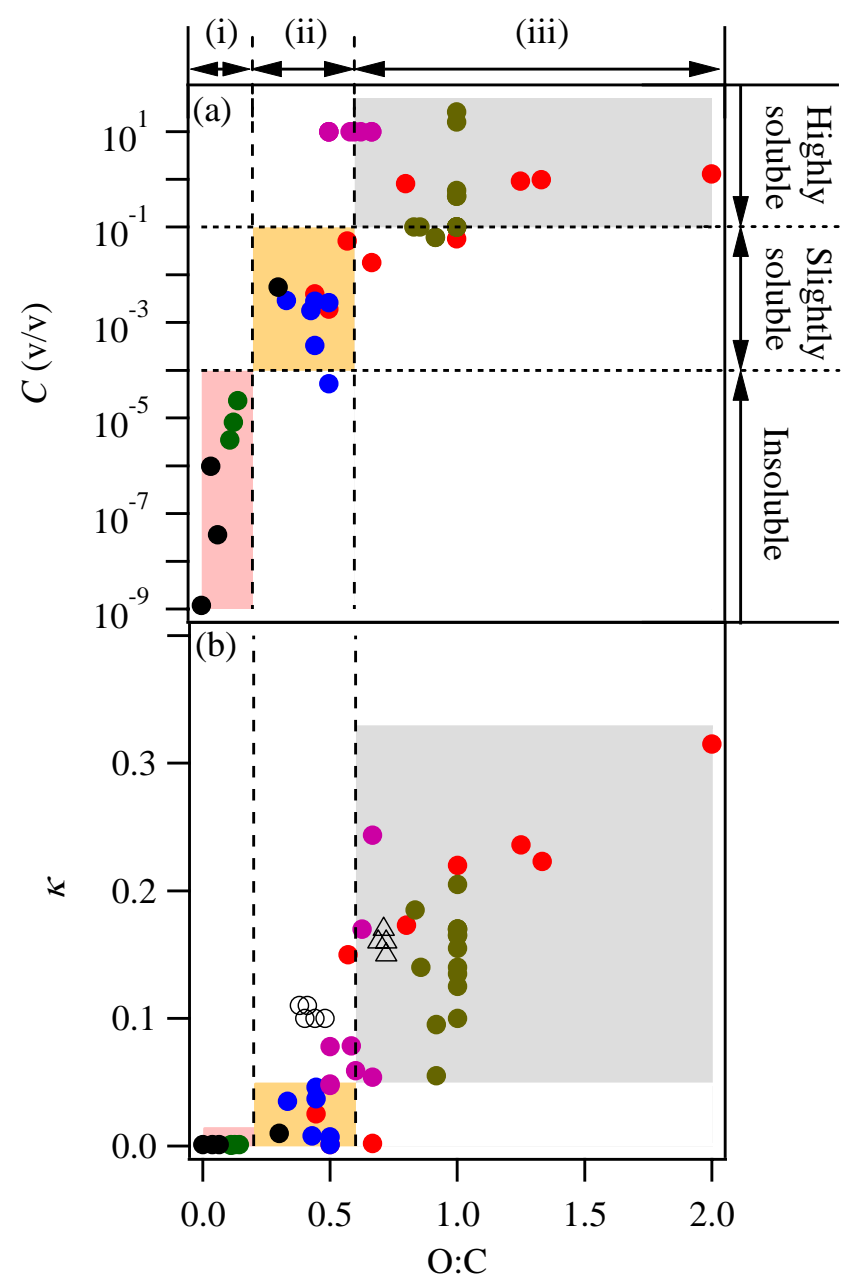

Fig. 3. Relationship of $\mathrm{O}: \mathrm{C}$ ratio to (a) $C$ and (b) $\kappa$. The colored areas in the panels highlight clustering among insoluble, slightly soluble, and highly soluble compounds. Compounds are listed in the Supplement.

(cf. Appendix A2). For $\mathrm{O}: \mathrm{C}>0.6$, most compounds are highly soluble.

The following equation empirically developed in the present study predicts $C$ from $\mathrm{O}: \mathrm{C}$ for the tested compounds:

$\ln C=20\left[(\mathrm{O}: \mathrm{C})^{0.402}-1\right]$

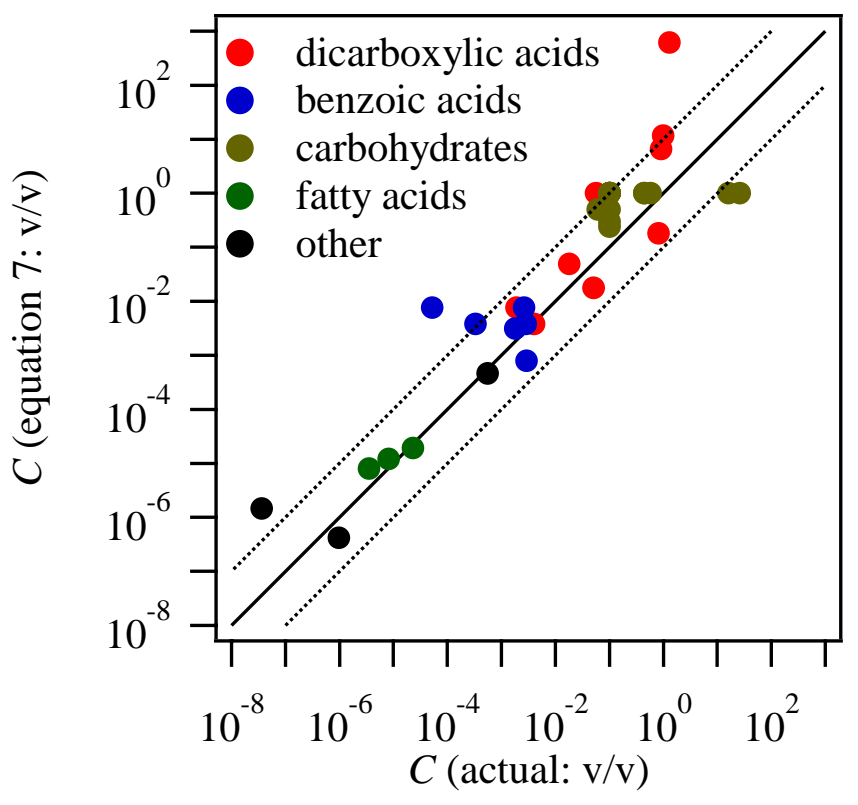

Fig. 4. Comparison of predicted $C$ (i.e., by $\mathrm{O}: \mathrm{C}$ ratio in Eq. 7) to its actual value. The solid line denotes a $1: 1$ line. The dashed lines correspond to 10-fold differences from the predictions of Eq. (7). The figure omits soluble polymers because they are miscible with water.

Figure 4 compares $C$ of the tested compounds with the predictions from Eq. (7). The values of $C$ for most of the tested compounds are predicted within an uncertainty of one order of magnitude, which is acceptably accurate considering that $C$ varies by ten orders of magnitudes. The observed correlation between $C$ and $\mathrm{O}: \mathrm{C}$ can be expected. Functional groups containing oxygen (e.g., $-\mathrm{OH},-\mathrm{COH}$, and $-\mathrm{COOH}$ ) increase $C$, as demonstrated in group contribution methods for predicting $C$ (Klopman et al., 1992).

\subsection{Relationship of $\kappa$ to $\mathrm{O}: \mathrm{C}$}

Figure $3 \mathrm{~b}$ shows the relationship between $\kappa$ and $\mathrm{O}: \mathrm{C}$. There are no $\mathrm{CCN}$-active compounds for $\mathrm{O}: \mathrm{C}<0.2$, as explained by the low values of $C$ (i.e., insoluble regime). For $0.2<\mathrm{O}: \mathrm{C}<0.6$, most compounds have low $\kappa$ values (i.e., $\kappa<0.05$ ) in correspondence to their slightly soluble values of $C$, i.e., as is consistent with the predictions from Köhler theory. CCN activation of these compounds occurs at deliquescence (i.e., the activation is limited thermodynamically by deliquescence) (Kreidenweis et al., 2006). The $\kappa$ values of synthetic polymers are an exception, having relatively high values of $0.05<\kappa<0.1$, which is explained by their high water solubility. For $\mathrm{O}: \mathrm{C}>0.6$, compounds are highly $\mathrm{CCN}$ active, having $\kappa>0.1$, as consistent with values of $C$ in the highly soluble regime. These observations point to a relationship between $\mathrm{CCN}$ activation and the $\mathrm{O}: \mathrm{C}$ value as (i) insoluble $(\mathrm{O}: \mathrm{C}<0.2)$, 
Table 5. Summary of compounds employed for Fig. 3. The complete list is available in the Supplement.

\begin{tabular}{llllll}
\hline Chemical family & $\mathrm{O}: \mathrm{C}$ & $\mathrm{H}: \mathrm{C}$ & $M_{\text {org }}\left(\mathrm{kg} \mathrm{mol}^{-1}\right)$ & $C(\mathrm{v} / \mathrm{v})$ & $\kappa$ \\
\hline Dicarboxylic acids & $0.44-2.00$ & $1.00-1.78$ & $0.090-0.188$ & $10^{-3}-10^{0}$ & $0.001-0.32$ \\
Benzoic acids & $0.33-0.50$ & $0.75-0.89$ & $0.138-0.180$ & $10^{-5}-10^{-3}$ & $0.001-0.037$ \\
Carbohydrates & $0.83-1.00$ & $1.60-2.50$ & $0.118-0.342$ & $\sim 10^{-1}$ & $0.06-0.21$ \\
Fatty acids & $0.11-0.14$ & $1.89-2.00$ & $0.228-0.284$ & $10^{-6}-10^{-5}$ & $\sim 0.001$ \\
Water-soluble $^{\text {a }}$ & $0.50-0.67$ & $1.33-2.33$ & $0.150-2.000$ & miscible & $0.05-0.24$ \\
polymers $_{\text {Other }}^{\mathrm{b}}$ & $0-0.30$ & $1.60-2.13$ & $0.184-0.387$ & $10^{-9}-10^{-3}$ & $0.001-0.01$ \\
\hline
\end{tabular}

${ }^{\text {a }}$ Mostly polymers of ethylene glycol, as reported by Petters et al. (2009a).

b Pinonic acid, hexadecane, hexadecanol, and cholesterol.

(ii) slightly soluble $(0.2<\mathrm{O}$ : $\mathrm{C}<0.6)$, or (iii) highly soluble $(0.6<\mathrm{O}: \mathrm{C})$ (Figs. 3 and 5).

For highly soluble particles, $\mathrm{CCN}$ activity is dominantly controlled by molar volume, which is determined by both $\rho_{\text {org }}$ and $1 / M_{\text {org }}$ (Eq. 5) (Petters et al., 2009a). Kuwata et al. (2012) developed a method to predict $\rho_{\text {org }}$ using $\mathrm{O}: \mathrm{C}$ and $\mathrm{H}: \mathrm{C}$ ratios. According to the method, $\rho_{\text {org }}$ is higher for highly oxygenated compounds. Even so, the range in $\rho_{\text {org }}$ values for $\mathrm{O}: \mathrm{C}>0.6$ from 1100 to $1650 \mathrm{~kg} \mathrm{~m}^{-3}$ is not sufficient to explain the variability observed for $\kappa$ for highly soluble materials. Furthermore, the $\rho_{\text {org }}$ values of carbohydrates and synthetic polymers do not vary significantly yet the variations in $\kappa$ is significant (cf. Supplement). The implication is that the dominant regulator of CCN activity is $M_{\text {org }}$ for highly soluble particles.

\subsection{CCN activity of SOM particles}

Isoprene $\mathrm{SOM}$ has an $\mathrm{O}: \mathrm{C}$ ratio of 0.7 and clusters with highly soluble compounds in a van Krevelen diagram (Fig. A2). In agreement, isoprene SOM is observed to activate as a highly soluble particle (King et al., 2010; Engelhart et al., 2011). Smith et al. (2012) found that isoprene SOM forms a homogeneous aqueous phase with ammonium sulfate solution for subsaturated relative humidity, further confirming that isoprene SOM is highly soluble. This result is consistent with the finding of Bertram et al. (2011) that liquid-liquid phase separation (i.e., formation of an insoluble phase) does not occur for highly oxygenated compounds $(\mathrm{O}: \mathrm{C}>0.7)$.

By comparison, $\alpha$-pinene SOM has a lower $\mathrm{O}: \mathrm{C}$ ratio of 0.3 to 0.5 . It clusters with slightly soluble compounds in a van Krevelen diagram (Fig. A2). One major molecular product is pinonic acid, which is slightly soluble ( $\mathrm{Yu}$ et al., 1999). Smith et al. (2011) reported that $\alpha$-pinene SOM phase separates in the subsaturated regime from aqueous ammonium sulfate, consistent with slightly soluble behavior. The experimental results for the CCN activity of $\alpha$-pinene SOM, however, suggest highly soluble particles (VanReken et al., 2005; Hartz et al., 2006; King et al., 2007; Petters et al., 2009b; Frosch et al., 2011; Kuwata et al., 2011). The gap between the understanding of pure compounds and $\alpha$-pinene SOM, which is composed of myriad compounds and undergoes continuous water uptake without deliquescence, needs to be investigated in more detail in the future.

The key point might be the absence of the thermodynamic deliquescence limitation. Unlike crystalline particles, amorphous particles, including $\alpha$-pinene SOM, continuously uptake water without the first order phase transition, meaning that particles form supersaturated liquid (Varutbangkul et al., 2006; Mikhailov et al., 2009; Kuwata and Martin, 2012b). Liquid adipic acid particles are much more $\mathrm{CCN}$ active than solid particles because their activation process is not limited by deliquescence (Bilde and Svenningsson, 2004). A similar phenomenon might occur for $\alpha$-pinene SOM. The role of particle phase on water uptake process of SOM particles would need to be investigated further to understand their $\mathrm{CCN}$ activation mechanisms.

\subsection{Atmospheric implications}

$\mathrm{Ng}$ et al. (2010) compiled observational data of O:C values for the Northern Hemisphere. The results showed that the $\mathrm{O}: \mathrm{C}$ value of ambient particles can vary from $\mathrm{O}: \mathrm{C}<0.2$, representing hydrocarbon-like organic material (HOA), to $\mathrm{O}: \mathrm{C}>0.2$, representing oxygenated organic material (OOA). Comparison of those $\mathrm{O}: \mathrm{C}$ values with the results of this study (Fig. 3) suggests, in conformance with expectation, that $\mathrm{HOA}$ is insoluble and $\mathrm{CCN}$ inactive whereas OOA is CCN active (Fig. 5). This conclusion is supported by the study of Mihara and Mochida (2011), which reported $\mathrm{O}: \mathrm{C}<0.2$ for water-insoluble atmospheric organic material.

Complexity in the chemical composition of organic aerosol particles must also be considered for application of this study's results to the categorization of atmospheric particles. A single particle typically consists of organic material from multiple sources and pathways, possibly influencing the relationship between CCN activity and chemical composition. Statistical data analysis, such as multivariate analysis of mass spectra, can sometimes succeed in characterizing those different types of organic materials 


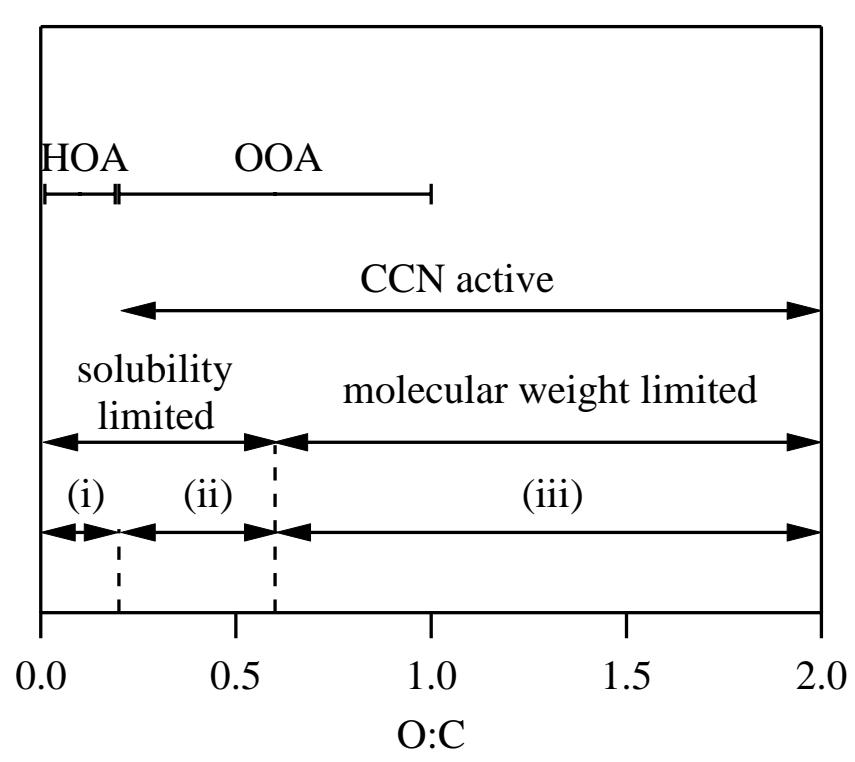

Fig. 5. Summary of the relationship between $\mathrm{CCN}$ activation mechanism and $\mathrm{O}: \mathrm{C}$ ratio. Regions representing (i) insoluble, (ii) slightly soluble, and (iii) highly soluble particles are highlighted. The $\mathrm{O}: \mathrm{C}$ ratios of hydrocarbon-like organic material (HOA) and oxygenated organic material (OOA) are also shown $(\mathrm{Ng}$ et al., 2010).

(Zhang et al., 2005; Ulbrich et al., 2009). Such an approach can be expected to be useful for further understanding and categorizing the $\mathrm{CCN}$ activity of atmospheric particles.

\section{Conclusions}

The CCN activity of pure organic compounds was investigated to develop a relationship between elemental ratios and $\mathrm{CCN}$ activation regimes. The results can serve as a basis for understanding the activation mechanisms of organic mixtures, such as secondary organic material. The experiments were conducted using a homogeneous nucleation particle generator to control the particle phase as a crystalline solid. This generation method was also advantageous for minimizing contamination. The experimental data demonstrated that $\mathrm{CCN}$ activation of adipic, suberic, azelaic, and pinonic acids are limited by deliquescence, consistent with the theoretical prediction. Pimelic acid behaved with respect CCN activation as a highly soluble compound, in agreement with reports in literature, though contrary to expectation as a slightly soluble compound.

The experimental results were combined with literature data, including those of dicarboxylic acids, benzoic acids, carbohydrates, fatty acids, and water soluble synthesized polymers. The dependence of $C$ on $\mathrm{O}: \mathrm{C}$ was demonstrated, leading to an approach for classifying $\mathrm{CCN}$ activation regimes. The effective hygroscopicity parameters $\kappa$ of pure organic compounds were plotted against $\mathrm{O}: \mathrm{C}$ ratios, confirming that activation mechanisms depend on $\mathrm{O}: \mathrm{C}$ ratios. The simplification of the molecular complexity to an $\mathrm{O}: \mathrm{C}$ parameter (Eq. 7; Fig. 5) could have high utility for incorporation of chemistry and chemistry feedbacks in larger-scale models, such as coupled climate-chemistry models.

Experimental results for SOM particles were compared with those for pure compounds. Isoprene SOM was clustered with highly soluble compounds in van Krevelen diagram, suggesting that $\mathrm{CCN}$ activation was not limited by solubility. This result was consistent with the $\kappa$ value as well as with formation of uniformly mixed particles at subsaturated regime. On the other hand, $\alpha$-pinene SOM was clustered by slightly soluble compounds on the van Krevelen diagram. In agreement, phase separation occurs for mixtures of $\alpha$-pinene SOM and ammonium sulfate for subsaturated RH (Smith et al., 2011). For supersaturated RH, however, $\alpha$-pinene SOM is highly CCN active. The activation mechanism of $\alpha$-pinene SOM has therefore been suggested as highly soluble, even though some $\alpha$-pinene oxidation products are slightly soluble. Particle phase as well as complexity in chemical composition may be important because they can remove the thermodynamic limitation of deliquescence for $\mathrm{CCN}$ activation. Comparison of these results with literature data on atmospheric organic materials indicate that hydrocarbon-like organic materials (HOA) are insoluble because of their low $\mathrm{O}: \mathrm{C}$ ratios $(<0.2)$ whereas oxygenated organic materials (OOA) are sufficiently soluble, suggesting the importance of OOA as a water-soluble contributor to atmospheric cloud life cycles.

\section{Appendix A}

\section{Temperature dependent solubility and $a_{\mathrm{w}, \mathrm{D}}$ of dicarboxylic acids}

Apelblat and Manzurola (1999) proposed the following equation representing temperature-dependent water solubility of organic acids:

$\ln (x)=\alpha+\frac{\beta}{T}+\gamma \ln (T)$

where $x$ is solubility in mole fraction, and $\alpha, \beta$, and $\gamma$ are empirical parameters obtained by fitting experimental data. This equation was employed to fit literature data, as summarized in Table A1 and Fig. A1. Assuming ideality in solution, $a_{\mathrm{w}, \mathrm{D}}$ can be calculated using the following equation (Marcolli et al., 2004)

$a_{\mathrm{w}, \mathrm{D}}=\exp \left(-M_{\mathrm{w}} m_{\mathrm{S}}\right)=\exp \left(-C \frac{M_{\mathrm{w}}}{M} \frac{\rho}{\rho_{\mathrm{w}}}\right)(A 2)$

where $m_{\mathrm{S}}$ corresponds to molality. This equation is derived from the definition of $\phi$ for $\phi=1$ (Robinson and Stokes, 2002). 


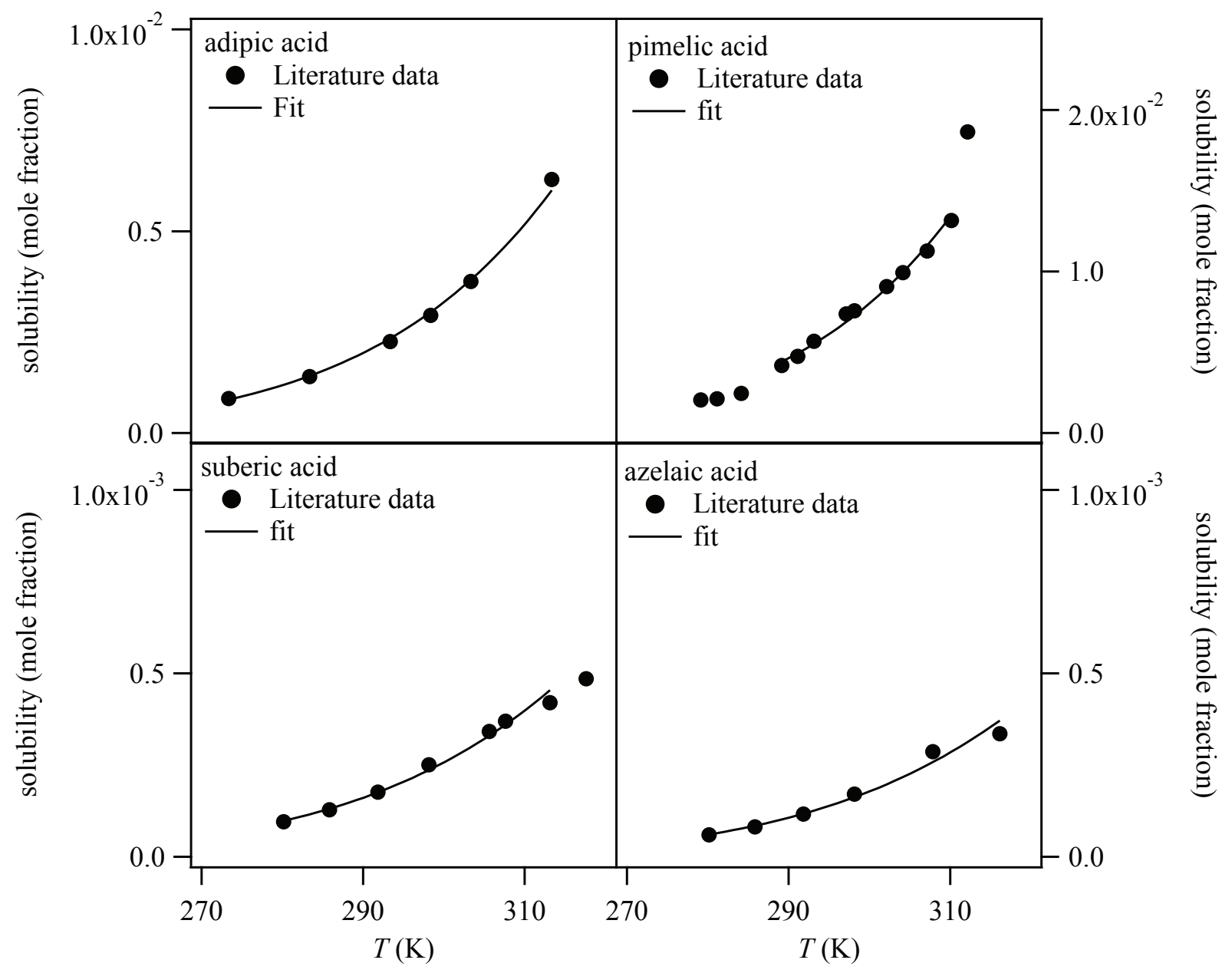

Fig. A1. Summary of solubility of adipic, pimelic, suberic, and azelaic acids as a function of temperature (Apelblat and Manzurola, 1989; 1990; Gaivoronskii and Granzhan, 2005). The fitting results are also shown (Eq. A1).

Table A1. Summary of parameters for the Apelblat-Manzurola equation (Eq. A1).

\begin{tabular}{lrrrll}
\hline Compound & $\alpha$ & $\beta$ & $\gamma$ & Temperature range (K) & Data source \\
\hline Adipic acid & -39.536 & -2146.1 & 7.1825 & $273.15<T<313.15$ & Gaivoronskii and Granzhan (2005) \\
Pimelic acid & 0.99162 & -4323.4 & 1.5065 & $289.15<T<310.15$ & Apelblat and Manzurola (1989) \\
Suberic acid & 15.391 & -4530 & -1.5003 & $280.15<T<313.15$ & Apelblat and Manzurola (1990) \\
Azelaic acid & 81.422 & -7783.7 & -11.24 & $280.15<T<316.15$ & Apelblat and Manzurola (1990) \\
\hline
\end{tabular}

\section{Appendix B}

\section{Van Krevelen diagram}

Figure A2 shows the Van Krevelen diagram of the pure compounds as well as that for SOM particles (Heald et al., 2010). Overall, a group of compounds form a cluster on the Van Krevelen diagram. For instance, the elemental ratios for dicarboxylic acids form a line. The relationships between $\mathrm{H}: \mathrm{C}$ and $\mathrm{O}: \mathrm{C}$ ratios are examined in Table $\mathrm{A} 2$, employing some simplifications. For instance, malic acid $\left(\mathrm{C}_{4} \mathrm{H}_{6} \mathrm{O}_{5}\right)$ has a hydroxyl group in between two carboxyl groups, yet this case was not considered in Table A2 to capture the general trends in Fig. A2.

Dicarboxylic acids form a line with a slope of -0.5 . This value is comparable to that reported in $\mathrm{Ng}$ et al. (2011) for atmospheric oxygenated organic compounds. $\mathrm{H}$ : $\mathrm{C}$ ratios of benzoic acids are much lower than those for other compounds, as aromatic carbons increase the denominator for $\mathrm{H}$ : $\mathrm{C}$ ratios significantly. $\mathrm{O}: \mathrm{C}$ ratios for carbonhydrates are around 1 , and $\mathrm{H}: \mathrm{C}$ ratios are approximately 2. $\mathrm{O}: \mathrm{C}$ ratios for fatty acids were small due to a long aliphatic 
Table A2. The positions and functions of each type of compounds on the van Krevelen diagram. $v_{\mathrm{C}}$, number of carbon atoms; $v_{\mathrm{H}}$, number of hydrogen atoms; $v_{\mathrm{O}}$ the number of oxygen atoms. The term $n_{x_{-} R_{i}}$ denotes the number of atoms $x$ in $R_{i}$. See Appendix A2 for detail.

\begin{tabular}{|c|c|c|c|c|c|c|}
\hline & $\nu_{\mathrm{C}}$ & $v_{\mathrm{H}}$ & $v_{\mathrm{O}}$ & $\mathrm{H}: \mathrm{C}$ & $\mathrm{O}: \mathrm{C}$ & Function \\
\hline $\begin{array}{l}\text { DOOC } \\
\text { Dicarboxylic acids }\end{array}$ & $2+n$ & $2+2 n$ & 4 & $\frac{2+2 n}{2+n}$ & $\frac{4}{2+n}$ & {$[\mathrm{H}: \mathrm{C}]=-\frac{[\mathrm{O}: \mathrm{C}]}{2}+2$} \\
\hline Benzoic acids & $6+\sum_{i} n_{\mathrm{C}_{R_{i}}}$ & $\sum_{i} n_{\mathrm{H}_{-} R_{i}}$ & $\sum_{i} n_{\mathrm{O}_{-} R_{i}}$ & $\frac{\sum_{i} n_{\mathrm{H}_{-} R_{i}}}{6+\sum_{i} n_{\mathrm{C}_{-} R_{i}}}$ & $\frac{\sum_{i} n_{\mathrm{O}_{-} R_{i}}}{6+\sum_{i} n_{\mathrm{C}_{-} R_{i}}}$ & {$[\mathrm{H}: \mathrm{C}]=\frac{\sum_{i} n_{\mathrm{H}_{-} R_{i}}}{\sum_{i} n_{\mathrm{O}_{-} R_{i}}}[\mathrm{O}: \mathrm{C}]$} \\
\hline $\begin{array}{l}\mathrm{C}_{m}\left(\mathrm{H}_{2} \mathrm{O}\right)_{n}{ }^{\mathrm{b}} \\
\text { Carbohydrates }\end{array}$ & $m$ & $2 n$ & $n$ & $\frac{2 n}{m}$ & $\frac{n}{m}$ & {$[\mathrm{H}: \mathrm{C}]=2[\mathrm{O}: \mathrm{C}]$} \\
\hline $\begin{array}{l}R-\mathrm{COOH} \\
\text { Fatty acids }\end{array}$ & $1+n_{c_{-} R}$ & $1+n_{\mathrm{H}_{-} R}$ & 2 & $\frac{1+n_{\mathrm{H} \_R}}{1+n_{\mathrm{C}-R}}$ & $\frac{2}{1+n_{\mathrm{C}_{-} R}}$ & {$[\mathrm{H}: \mathrm{C}]=\frac{1+n_{\mathrm{H}_{-} R}}{2}[\mathrm{O}: \mathrm{C}]$} \\
\hline $\begin{array}{l}\text { Polyethylene glycol } \\
\text { Pol }\end{array}$ & $2 n$ & $2+4 n$ & $1+n$ & $\frac{1+2 n}{n}$ & $\frac{1+n}{2 n}$ & {$[\mathrm{H}: \mathrm{C}]=2[\mathrm{O}: \mathrm{C}]+1$} \\
\hline
\end{tabular}

\footnotetext{
a There are exceptions (e.g., malic acid).

b There are exceptions (e.g., xylitol.)
}

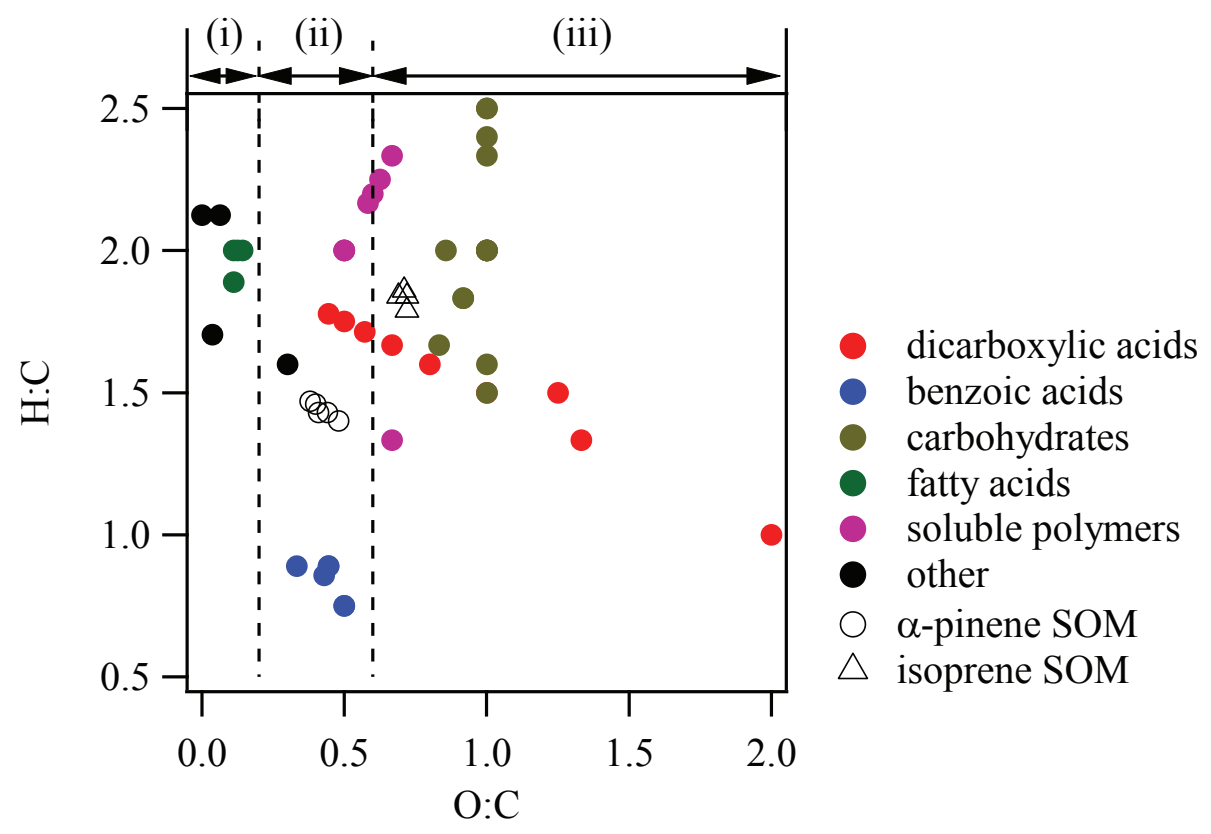

Fig. A2. Relationships between $\mathrm{O}: \mathrm{C}$ and $\mathrm{H}: \mathrm{C}$ ratios of pure compounds and SOM (van Krevelen diagram). The regions (i)-(iii) indicates (i) insoluble, (ii) slightly soluble, and (iii) highly soluble regimes, respectively (see the main text for detail).

chain. $\mathrm{H}: \mathrm{C}$ ratios for those compounds are also similar to aliphatic compounds. Polyethylene glycol was employed as an example for synthetic polymers (Petters et al., 2009a). $\mathrm{H}: \mathrm{C}$ ratios of those polymers decrease with the slope of 2 , as a dehydration (etherification) mechanism involves in the formation of those polymers (Heald et al., 2010; Kuwata et al., 2011). Overall, Figure A2 demonstrates that a van Krevelen diagram is useful in classifying atmospheric relevant pure compounds. 


\section{Supplementary material related to this article is available online at: http://www.atmos-chem-phys.net/13/ 5309/2013/acp-13-5309-2013-supplement.pdf.}

Acknowledgements. This research was supported by the the Office of Science (BER), US Department of Energy. M. K. acknowledges the support from the Japan Society for the Promotion of Science (JSPS) for the postdoctoral fellowship research abroad. Q. Chen, Y. Liu, M. L. Smith, and S. R. Zorn are acknowledged for assistance with the experiments and useful discussion.

Edited by: V. F. McNeill

\section{References}

Apelblat, A. and Manzurola, E.: Solubility of ascorbic, 2furancarboxylic, glutaric, pimelic, salicyclic, and o-phthalic acids in water from $279.15-\mathrm{K}$ to $342.15-\mathrm{K}$, and apparent molar volumes of ascorbic, glutaric, amd pimelic acids in water at 298.15-K, J. Chem. Thermodyn., 21, 1005-1008, doi:10.1016/0021-9614(89)90161-4, 1989.

Apelblat, A. and Manzurola, E.: Solubility of suberic, azelaic, levulinic, glycolic, and diglycolic acids in water from 278.25-K to 361.35-K, J. Chem. Thermodyn., 22, 289-292, doi:10.1016/0021-9614(90)90201-z, 1990.

Apelblat, A. and Manzurola, E.: Solubilities of o-acetylsalicylic, 4-aminosalicylic, 3,5-dinitrosalicylic, and p-toluic acid, and magnesium-DL-aspartate in water from $\mathrm{T}=(278$ to 348$) \mathrm{K}$, J. Chem. Thermodyn., 31, 85-91, doi:10.1006/jcht.1998.0424, 1999.

Asa-Awuku, A., Engelhart, G. J., Lee, B. H., Pandis, S. N., and Nenes, A.: Relating CCN activity, volatility, and droplet growth kinetics of $\beta$-caryophyllene secondary organic aerosol, Atmos. Chem. Phys., 9, 795-812, doi:10.5194/acp-9-795-2009, 2009.

Bertram, A. K., Martin, S. T., Hanna, S. J., Smith, M. L., Bodsworth, A., Chen, Q., Kuwata, M., Liu, A., You, Y., and Zorn, S. R.: Predicting the relative humidities of liquid-liquid phase separation, efflorescence, and deliquescence of mixed particles of ammonium sulfate, organic material, and water using the organic-to-sulfate mass ratio of the particle and the oxygen-to-carbon elemental ratio of the organic component, Atmos. Chem. Phys., 11, 10995-11006, doi:10.5194/acp-11-10995-2011, 2011.

Bilde, M. and Svenningsson, B.: CCN activation of slightly soluble organics: the importance of small amounts of inorganic salt and particle phase, Tellus Series B, 56, 128-134, doi:10.1111/j.16000889.2004.00090.x, 2004.

Biskos, G., Buseck, P. R., and Martin, S. T.: Hygroscopic growth of nucleation-mode acidic sulfate particles, J. Aerosol Sci., 40, 338-347, doi:10.1016/j.jaerosci.2008.12.003, 2009.

Broekhuizen, K., Kumar, P. P., and Abbatt, J. P. D.: Partially soluble organics as cloud condensation nuclei: Role of trace soluble and surface active species, Geophys. Res. Lett., 31, L01107, doi:10.1029/2003g1018203, 2004.

Chan, M. N., Kreidenweis, S. M., and Chan, C. K.: Measurements of the hygroscopic and deliquescence properties of organic compounds of different solubilities in water and their relationship with cloud condensation nuclei activities, Environ. Sci. Technol., 42, 3602-3608. doi:10.1021/es7023252, 2008.

Chang, R. Y.-W., Slowik, J. G., Shantz, N. C., Vlasenko, A., Liggio, J., Sjostedt, S. J., Leaitch, W. R., and Abbatt, J. P. D.: The hygroscopicity parameter $(\kappa)$ of ambient organic aerosol at a field site subject to biogenic and anthropogenic influences: relationship to degree of aerosol oxidation, Atmos. Chem. Phys., 10, 5047-5064, doi:10.5194/acp-10-5047-2010, 2010.

Chen, Q., Liu, Y. J., Donahue, N. M., Shilling, J. E. and Martin, S. T.: Particle-phase chemistry of secondary organic material: modeled compared to measured $\mathrm{O}: \mathrm{C}$ and $\mathrm{H}: \mathrm{C}$ elemental ratios provide constraints, Environ. Sci. Technol., 45, 4763-4770. doi:10.1021/es104398s, 2011.

Christensen, S. I. and Petters, M. D.: The Role of Temperature in Cloud Droplet Activation, J. Phys. Chem. A, 116, 9706-9717, doi:10.1021/jp3064454, 2012.

Clegg, S. L. and Seinfeld, J. H.: Thermodynamic models of aqueous solutions containing inorganic electrolytes and dicarboxylic acids at 298.15 K. 2. Systems including dissociation equilibria, J. Phys. Chem. A, 110, 5718-5734, doi:10.1021/jp056150j, 2006.

Corrigan, C. E. and Novakov, T.: Cloud condensation nucleus activity of organic compounds: a laboratory study, Atmos. Environ., 33, 2661-2668, doi:10.1016/s1352-2310(98)00310-0, 1999.

Cruz, C. N. and Pandis, S. N.: A study of the ability of pure secondary organic aerosol to act as cloud condensation nuclei, Atmos. Environ., 31, 2205-2214, doi:10.1016/s13522310(97)00054-x, 1997.

DeCarlo, P. F., Kimmel, J. R., Trimborn, A., Northway, M. J., Jayne, J. T., Aiken, A. C., Gonin, M., Fuhrer, K., Horvath, T., Docherty, K. S., Worsnop, D. R., and Jimenez, J. L.: Field-deployable, high-resolution, time-of-flight aerosol mass spectrometer, Anal. Chem., 78, 8281-8289, doi:10.1021/ac061249n, 2006.

Dusek, U., Frank, G. P., Hildebrandt, L., Curtius, J., Schneider, J., Walter, S., Chand, D., Drewnick, F., Hings, S., Jung, D., Borrmann, S., and Andreae, M. O.: Size matters more than chemistry for cloud-nucleating ability of aerosol particles, Science, 312, 1375-1378, doi:10.1126/science.1125261, 2006.

Ehara, K., Hagwood, C., and Coakley, K. J.: Novel method to classify aerosol particles according to their mass-to-charge ratio - Aerosol particle mass analyser, J. Aerosol Sci, 27, 217-234, doi:10.1016/0021-8502(95)00562-5, 1996.

Engelhart, G. J., Moore, R. H., Nenes, A., and Pandis, S. N.: Cloud condensation nuclei activity of isoprene secondary organic aerosol, J. Geophys. Res., 116, D02207, doi:10.1029/2010jd014706, 2011.

Frosch, M., Zardini, A. A., Platt, S. M., Müller, L., Reinnig, M.C., Hoffmann, T., and Bilde, M.: Thermodynamic properties and cloud droplet activation of a series of oxo-acids, Atmos. Chem. Phys., 10, 5873-5890, doi:10.5194/acp-10-5873-2010, 2010.

Frosch, M., Bilde, M., DeCarlo, P. F., Juranyi, Z., Tritscher, T., Dommen, J., Donahue, N. M., Gysel, M., Weingartner, E., and Baltensperger, U.: Relating cloud condensation nuclei activity and oxidation level of alpha-pinene secondary organic aerosols, J. Geophys. Res., 116, D22212, doi:10.1029/2011jd016401, 2011.

Gaivoronskii, A. N. and Granzhan, V. A.: Solubility of adipic acid in organic solvents and water, Russ. J. Appl. Chem., 78, 404-408, 
doi:10.1007/s11167-005-0305-0, 2005.

Hallquist, M., Wenger, J. C., Baltensperger, U., Rudich, Y., Simpson, D., Claeys, M., Dommen, J., Donahue, N. M., George, C., Goldstein, A. H., Hamilton, J. F., Herrmann, H., Hoffmann, T., Iinuma, Y., Jang, M., Jenkin, M. E., Jimenez, J. L., Kiendler-Scharr, A., Maenhaut, W., McFiggans, G., Mentel, Th. F., Monod, A., Prévôt, A. S. H., Seinfeld, J. H., Surratt, J. D., Szmigielski, R., and Wildt, J.: The formation, properties and impact of secondary organic aerosol: current and emerging issues, Atmos. Chem. Phys., 9, 5155-5236, doi:10.5194/acp-9-5155-2009, 2009.

Hartz, K. E. H., Rosenorn, T., Ferchak, S. R., Raymond, T. M., Bilde, M., Donahue, N. M., and Pandis, S. N.: Cloud condensation nuclei activation of monoterpene and sesquiterpene secondary organic aerosol, J. Geophys. Res., 110, D14208, doi:10.1029/2004jd005754, 2005.

Hartz, K. E. H., Tischuk, J. E., Chan, M. N., Chan, C. K., Donahue, N. M., and Pandis, S. N.: Cloud condensation nuclei activation of limited solubility organic aerosol, Atmos. Environ., 40, 605-617, doi:10.1016/j.atmosenv.2005.09.076, 2006.

Heald, C. L., Kroll, J. H., Jimenez, J. L., Docherty, K. S., DeCarlo, P. F., Aiken, A. C., Chen, Q., Martin, S. T., Farmer, D. K., and Artaxo, P.: A simplified description of the evolution of organic aerosol composition in the atmosphere, Geophys. Res. Lett., 37, L08803, doi:10.1029/2010g1042737, 2010.

Hings, S. S., Wrobel, W. C., Cross, E. S., Worsnop, D. R., Davidovits, P., and Onasch, T. B.: CCN activation experiments with adipic acid: effect of particle phase and adipic acid coatings on soluble and insoluble particles, Atmos. Chem. Phys., 8, 3735-3748, doi:10.5194/acp-8-3735-2008, 2008.

Hori, M., Ohta, S., Murao, N., and Yamagata, S.: Activation capability of water soluble organic substances as CCN, J. Aerosol Sci., 34, 419-448, doi:10.1016/s0021-8502(02)00190-8, 2003.

Jimenez, J. L., Canagaratna, M. R., Donahue, N. M., Prevot, A. S. H., Zhang, Q., Kroll, J. H., DeCarlo, P. F., Allan, J. D., Coe, H., Ng, N. L., Aiken, A. C., Docherty, K. S., Ulbrich, I. M., Grieshop, A. P., Robinson, A. L., Duplissy, J., Smith, J. D., Wilson, K. R., Lanz, V. A., Hueglin, C., Sun, Y. L., Tian, J., Laaksonen, A., Raatikainen, T., Rautiainen, J., Vaattovaara, P., Ehn, M., Kulmala, M., Tomlinson, J. M., Collins, D. R., Cubison, M. J., Dunlea, E. J., Huffman, J. A., Onasch, T. B., Alfarra, M. R., Williams, P. I., Bower, K., Kondo, Y., Schneider, J., Drewnick, F., Borrmann, S., Weimer, S., Demerjian, K., Salcedo, D., Cottrell, L., Griffin, R., Takami, A., Miyoshi, T., Hatakeyama, S., Shimono, A., Sun, J. Y., Zhang, Y. M., Dzepina, K., Kimmel, J. R., Sueper, D., Jayne, J. T., Herndon, S. C., Trimborn, A. M., Williams, L. R., Wood, E. C., Middlebrook, A. M., Kolb, C. E., Baltensperger, U., and Worsnop, D. R.: Evolution of organic aerosols in the atmosphere, Science, 326, 1525-1529, doi:10.1126/science.1180353, 2009.

King, S. M., Rosenoern, T., Shilling, J. E., Chen, Q., and Martin, S. T.: Cloud condensation nucleus activity of secondary organic aerosol particles mixed with sulfate, Geophys. Res. Lett., 34, L24806, doi:10.1029/2007g1030390, 2007.

King, S. M., Rosenoern, T., Shilling, J. E., Chen, Q., and Martin, S. T.: Increased cloud activation potential of secondary organic aerosol for atmospheric mass loadings, Atmos. Chem. Phys., 9, 2959-2971, doi:10.5194/acp-9-2959-2009, 2009.
King, S. M., Rosenoern, T., Shilling, J. E., Chen, Q., Wang, Z., Biskos, G., McKinney, K. A., Pöschl, U., and Martin, S. T.: Cloud droplet activation of mixed organic-sulfate particles produced by the photooxidation of isoprene, Atmos. Chem. Phys., 10, 3953-3964, doi:10.5194/acp-10-3953-2010, 2010.

Klopman, G., Wang, S., and Balthasar, D. M.: Estimation of aqueous solubility of organic-molecules by the group contribution approach - application to the study of biodegradation, J. Chem. Inf. Comp. Sci., 32, 474-482, doi:10.1021/ci00009a013, 1992.

Köhler, H.: The nucleus in and the growth of hygroscopic droplets, T. Faraday Soc., 32, 1152-1161, doi:10.1039/TF9363201152, 1936.

Kreidenweis, S. M., Petters, M. D., and DeMott, P. J.: Deliquescence-controlled activation of organic aerosols, Geophys. Res. Lett., 33, L06801, doi:10.1029/2005g1024863, 2006.

Kuwata, M. and Kondo, Y.: Measurements of particle masses of inorganic salt particles for calibration of cloud condensation nuclei counters, Atmos. Chem. Phys., 9, 5921-5932, doi:10.5194/acp-9-5921-2009, 2009.

Kuwata, M., Kondo, Y., Miyazaki, Y., Komazaki, Y., Kim, J. H., Yum, S. S., Tanimoto, H., and Matsueda, H.: Cloud condensation nuclei activity at Jeju Island, Korea in spring 2005, Atmos. Chem. Phys., 8, 2933-2948, doi:10.5194/acp-8-2933-2008, 2008.

Kuwata, M. and Martin, S. T.: Particle Size Distributions following Condensational Growth in Continuous Flow Aerosol Reactors as Derived from Residence Time Distributions: Theoretical Development and Application to Secondary Organic Aerosol, Aerosol Sci. Technol., 46, 937-949, doi:10.1080/02786826.2012.683204, 2012a.

Kuwata, M. and Martin, S. T.: The phase of atmospheric organic particles affects their reactivity, Proc. Natl. Acad. Sci. USA, 109, 17354-17359. doi:10.1073/pnas.1209071109, 2012b.

Kuwata, M., Chen, Q., and Martin, S. T.: Cloud condensation nuclei $(\mathrm{CCN})$ activity and oxygen-to-carbon elemental ratios following thermodenuder treatment of organic particles grown by $\alpha$-pinene ozonolysis, Phys. Chem. Phys., 13, 14571-14583, doi:10.1039/c1cp20253g, 2011.

Kuwata, M., Zorn, S. R., and Martin, S. T.: Using elemental ratios to predict the density of organic material composed of carbon, hydrogen, and oxygen, Environ. Sci. Technol., 46, 787-794, doi:10.1021/es202525q, 2012.

Lambe, A. T., Onasch, T. B., Massoli, P., Croasdale, D. R., Wright, J. P., Ahern, A. T., Williams, L. R., Worsnop, D. R., Brune, W. H., and Davidovits, P.: Laboratory studies of the chemical composition and cloud condensation nuclei (CCN) activity of secondary organic aerosol (SOA) and oxidized primary organic aerosol (OPOA), Atmos. Chem. Phys., 11, 8913-8928, doi:10.5194/acp-11-8913-2011, 2011.

Lathem, T. L. and Nenes, A.: Water Vapor Depletion in the DMT Continuous-Flow CCN Chamber: Effects on Supersaturation and Droplet Growth, Aerosol Sci. Technol., 45, 604-615, doi:10.1080/02786826.2010.551146, 2011.

Marcolli, C., Luo, B. P., and Peter, T.: Mixing of the organic aerosol fractions: Liquids as the thermodynamically stable phases, J. Phys. Chem. A, 108, 2216-2224, doi:10.1021/jp0360801, 2004.

McFiggans, G., Artaxo, P., Baltensperger, U., Coe, H., Facchini, M. C., Feingold, G., Fuzzi, S., Gysel, M., Laaksonen, A., Lohmann, U., Mentel, T. F., Murphy, D. M., O’Dowd, C. D., Snider, J. R., 
and Weingartner, E.: The effect of physical and chemical aerosol properties on warm cloud droplet activation, Atmos. Chem. Phys., 6, 2593-2649, doi:10.5194/acp-6-2593-2006, 2006.

McMurry, P. H., Wang, X., Park, K., and Ehara, K.: The relationship between mass and mobility for atmospheric particles: A new technique for measuring particle density, Aerosol Sci. Technol., 36, 227-238, doi:10.1080/027868202753504083, 2002.

Mihara, T. and Mochida, M.: Characterization of solventextractable organics in urban aerosols based on mass spectrum analysis and hygroscopic growth measurement, Environ. Sci. Technol., 45, 9168-9174, doi:10.1021/es201271w, 2011.

Mikhailov, E., Vlasenko, S., Martin, S. T., Koop, T., and Pöschl, U.: Amorphous and crystalline aerosol particles interacting with water vapor: conceptual framework and experimental evidence for restructuring, phase transitions and kinetic limitations, Atmos. Chem. Phys., 9, 9491-9522, doi:10.5194/acp-9-9491-2009, 2009.

Ng, N. L., Canagaratna, M. R., Zhang, Q., Jimenez, J. L., Tian, J., Ulbrich, I. M., Kroll, J. H., Docherty, K. S., Chhabra, P. S., Bahreini, R., Murphy, S. M., Seinfeld, J. H., Hildebrandt, L., Donahue, N. M., DeCarlo, P. F., Lanz, V. A., Prévôt, A. S. H., Dinar, E., Rudich, Y., and Worsnop, D. R.: Organic aerosol components observed in Northern Hemispheric datasets from Aerosol Mass Spectrometry, Atmos. Chem. Phys., 10, 4625-4641, doi:10.5194/acp-10-4625-2010, 2010.

Ng, N. L., Canagaratna, M. R., Jimenez, J. L., Chhabra, P. S., Seinfeld, J. H., and Worsnop, D. R.: Changes in organic aerosol composition with aging inferred from aerosol mass spectra, Atmos. Chem. Phys., 11, 646-6474, doi:10.5194/acp-11-64652011, 2011.

Novakov, T. and Penner, J. E.: Large contribution of organic aerosols to cloud-condensation-nuclei concentrations, Nature, 365, 823-826, doi:10.1038/365823a0, 1993.

O’Brien, R. E., Laskin, A., Laskin, J., Liu, S., Weber, R., Russell, L. M., and Goldstein, A. H.: Molecular characterization of organic aerosol using nanospray desorption/electrospray ionization mass spectrometry: CalNex 2010 field study, Atmos. Environ., 68, 265-272, doi:10.1016/j.atmosenv.2012.11.056, 2013.

Petters, M. D. and Kreidenweis, S. M.: A single parameter representation of hygroscopic growth and cloud condensation nucleus activity, Atmos. Chem. Phys., 7, 1961-1971, doi:10.5194/acp-7-1961-2007, 2007.

Petters, M. D. and Kreidenweis, S. M.: A single parameter representation of hygroscopic growth and cloud condensation nucleus activity - Part 2: Including solubility, Atmos. Chem. Phys., 8, 6273-6279, doi:10.5194/acp-8-6273-2008, 2008.

Petters, M. D., Kreidenweis, S. M., Prenni, A. J., Sullivan, R. C., Carrico, C. M., Koehler, K. A., and Ziemann, P. J.: Role of molecular size in cloud droplet activation, Geophys. Res. Lett., 36, L22801, doi:10.1029/2009gl040131, 2009a.

Petters, M. D., Wex, H., Carrico, C. M., Hallbauer, E., Massling, A., McMeeking, G. R., Poulain, L., Wu, Z., Kreidenweis, S. M., and Stratmann, F.: Towards closing the gap between hygroscopic growth and activation for secondary organic aerosol - Part 2: Theoretical approaches, Atmos. Chem. Phys., 9, 3999-4009, doi:10.5194/acp-9-3999-2009, 2009b.

Pradeep Kumar, P., Broekhuizen, K., and Abbatt, J. P. D.: Organic acids as cloud condensation nuclei: Laboratory studies of highly soluble and insoluble species, Atmos. Chem. Phys., 3, 509-520, doi:10.5194/acp-3-509-2003, 2003.

Prenni, A. J., DeMott, P. J., Kreidenweis, S. M., Sherman, D. E., Russell, L. M., and Ming, Y.: The effects of low molecular weight dicarboxylic acids on cloud formation, J. Phys. Chem. A, 105, 11240-11248, doi:10.1021/jp012427d, 2001.

Ramanathan, V., Crutzen, P. J., Kiehl, J. T., and Rosenfeld, D.: Atmosphere - Aerosols, climate, and the hydrological cycle, Science, 294, 2119-2124, doi:10.1126/science.1064034, 2001.

Raymond, T. M. and Pandis, S. N.: Cloud activation of single-component organic aerosol particles, J. Geophys. Res., 107, 4787, doi:10.1029/2002jd002159, 2002.

Rissman, T. A., Varutbangkul, V., Surratt, J. D., Topping, D. O., McFiggans, G., Flagan, R. C., and Seinfeld, J. H.: Cloud condensation nucleus $(\mathrm{CCN})$ behavior of organic aerosol particles generated by atomization of water and methanol solutions, Atmos. Chem. Phys., 7, 2949-2971, doi:10.5194/acp-7-2949-2007, 2007.

Roberts, G. C. and Nenes, A.: A continuous-flow streamwise thermal-gradient $\mathrm{CCN}$ chamber for atmospheric measurements, Aerosol Sci. Technol., 39, 206-221, doi:10.1080/027868290913988, 2005.

Robinson, R. A. and Stokes, R. H.: Electrolyte Solutions: Second Revised Edition, Dover Publications, Mineola, New York, 2002.

Rosenorn, T., Kiss, G., and Bilde, M.: Cloud droplet activation of saccharides and levoglucosan particles, Atmos. Environ., 40, 1794-1802, doi:10.1016/j.atmosenv.2005.11.024, 2006.

Ruehl, C. R., Chuang, P. Y., and Nenes, A.: How quickly do cloud droplets form on atmospheric particles?, Atmos. Chem. Phys., 8, 1043-1055, doi:10.5194/acp-8-1043-2008, 2008.

Seinfeld, J. H. and Pandis, S. N.: Atmospheric Chemistry and Physics, Wiley-Interscience, 2006.

Shao, W.: Cloud condensation nuclei activities of crystalline organic particles, Harvard University, Master of Engineering, 2012.

Shilling, J. E., King, S. M., Mochida, M., and Martin, S. T.: Mass spectral evidence that small changes in composition caused by oxidative aging processes alter aerosol CCN properties, J. Phys. Chem. A, 111, 3358-3368, doi:10.1021/jp068822r, 2007.

Shilling, J. E., Chen, Q., King, S. M., Rosenoern, T., Kroll, J. H., Worsnop, D. R., McKinney, K. A., and Martin, S. T.: Particle mass yield in secondary organic aerosol formed by the dark ozonolysis of $\alpha$-pinene, Atmos. Chem. Phys., 8, 2073-2088, doi:10.5194/acp-8-2073-2008, 2008.

Shulman, M. L., Jacobson, M. C., Carlson, R. J., Synovec, R. E., and Young, T. E.: Dissolution behavior and surface tension effects of organic compounds in nucleating cloud droplets, Geophys. Res. Lett., 23, 277-280, doi:10.1029/95g103810, 1996.

Smith, M. L., Kuwata, M., and Martin, S. T.: Secondary Organic Material Produced by the Dark Ozonolysis of alpha-Pinene Minimally Affects the Deliquescence and Efflorescence of Ammonium Sulfate, Aerosol Sci. Technol., 45, 244-261, doi:10.1080/02786826.2010.532178, 2011.

Smith, M. L., Bertram, A. K., and Martin, S. T.: Deliquescence, efflorescence, and phase miscibility of mixed particles of ammonium sulfate and isoprene-derived secondary organic material, Atmos. Chem. Phys., 12, 9613-9628, doi:10.5194/acp12-9613-2012, 2012.

Stevens, B. and Feingold, G.: Untangling aerosol effects on clouds and precipitation in a buffered system, Nature, 461, 607-613, 
doi:10.1038/nature08281, 2009.

Sullivan, R. C., Moore, M. J. K., Petters, M. D., Kreidenweis, S. M., Roberts, G. C., and Prather, K. A.: Effect of chemical mixing state on the hygroscopicity and cloud nucleation properties of calcium mineral dust particles, Atmos. Chem. Phys., 9, 33033316, doi:10.5194/acp-9-3303-2009, 2009.

Twomey, S.: Influence of pollution on shortwave albedo of clouds, J. Atmos. Sci., 34, 1149-1152, doi:10.1175/15200469(1977)034<1149:tiopot>2.0.co;2, 1977.

Ulbrich, I. M., Canagaratna, M. R., Zhang, Q., Worsnop, D. R., and Jimenez, J. L.: Interpretation of organic components from Positive Matrix Factorization of aerosol mass spectrometric data, Atmos. Chem. Phys., 9, 2891-2918, doi:10.5194/acp-9-28912009, 2009.

VanReken, T. M., Ng, N. L., Flagan, R. C., and Seinfeld, J. H.: Cloud condensation nucleus activation properties of biogenic secondary organic aerosol, J. Geophys. Res., 110, D07206, doi:10.1029/2004jd005465, 2005.

Varutbangkul, V., Brechtel, F. J., Bahreini, R., Ng, N. L., Keywood, M. D., Kroll, J. H., Flagan, R. C., Seinfeld, J. H., Lee, A., and Goldstein, A. H.: Hygroscopicity of secondary organic aerosols formed by oxidation of cycloalkenes, monoterpenes, sesquiterpenes, and related compounds, Atmos. Chem. Phys., 6, 2367-2388, doi:10.5194/acp-6-2367-2006, 2006.
Wex, H., Petters, M. D., Carrico, C. M., Hallbauer, E., Massling, A., McMeeking, G. R., Poulain, L., Wu, Z., Kreidenweis, S. M., and Stratmann, F.: Towards closing the gap between hygroscopic growth and activation for secondary organic aerosol: Part 1 - Evidence from measurements, Atmos. Chem. Phys., 9, 3987-3997, doi:10.5194/acp-9-3987-2009, 2009.

Yu, J. Z., Cocker, D. R., Griffin, R. J., Flagan, R. C., and Seinfeld, J. H.: Gas-phase ozone oxidation of monoterpenes: Gaseous and particulate products, J. Atmos. Chem., 34, 207-258, 1999.

Zhang, Q., Alfarra, M. R., Worsnop, D. R., Allan, J. D., Coe, H., Canagaratna, M. R., and Jimenez, J. L.: Deconvolution and quantification of hydrocarbon-like and oxygenated organic aerosols based on aerosol mass spectrometry, Environ. Sci. Technol., 39, 4938-4952, doi:10.1021/es0485681, 2005. 